Portland State University

PDXScholar

5-16-1975

\title{
A survey and critical analysis of current literature on the post audit of capital expenditure
}

Gene Albert Katke

Portland State University

Follow this and additional works at: https://pdxscholar.library.pdx.edu/open_access_etds

Part of the Business Administration, Management, and Operations Commons, and the Corporate Finance Commons

Let us know how access to this document benefits you.

\section{Recommended Citation}

Katke, Gene Albert, "A survey and critical analysis of current literature on the post audit of capital expenditure" (1975). Dissertations and Theses. Paper 2253.

https://doi.org/10.15760/etd.2250

This Thesis is brought to you for free and open access. It has been accepted for inclusion in Dissertations and Theses by an authorized administrator of PDXScholar. Please contact us if we can make this document more accessible: pdxscholar@pdx.edu. 
AN ABSTRACT OF THE THESIS OF Gene Albert Katke for the Master of Business Administration presented May 16, 1975.

Title: A SURVEY AND CRITICAL ANALYSIS OF CURRENT LITERATURE ON THE POST AUDIT OF CAPITAL EXPENDITURES

APPROVED BY MEMBERS OF THE THESIS COMMITTEE:

$$
\text { Dr. LeRoy A. Hewitt, Chairman }
$$

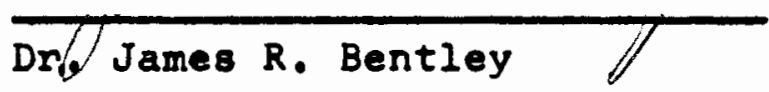

Dr. Emerson Hoofsstraat

Several writers in the field of capital budgeting have charged that present day literature on the subject fails to adequately address the post audit phase of capital expenditure programs. This study is essentially a survey of current literature designed to determine the validity of this charge. To accomplish this task, the study compares each authors' published views on selected post audit factors with other responses from the literature and analyzes collective agreements and differences. Armed with this information, an 
attempt is made to provide answers to three pertinent questions :

1. Does general agreement exist among writers on what constitutes the basic elements of post auditing?

2. Within each of these basic elements, has the literature established a generally accepted set of operating principles to guide the practitioner?

3. In general, has the literature to date, individually or collectively, presented an approach to post auditing which is sufficiently structured to enable the practitioner to develop an effective post auditing program and to proceed with implementation?

Research material was gathered from library and bibliographical references with the intent of including most of the articles currently available on post audit. From this research, forty-four articles were found to contain sufficient material to be included in the survey.

The survey itself was structured around seven basic elements of post auditing which were selected after a thorough search of the literature revealed them to be the only items of substantial interest to the authors involved.

1. Purpose and importance

2. Project selection

3. Audit factors 
4. Sources of information

5. Audit timing

6. Audit responsibility

7. Prerequisite actions

For each element, the authors' positions were summarized into a comparative listing to establish the extent of general agreement prevailing in the literature. Additional analysis was performed for each element to determine the degree to which practical direction is available to the practitioner.

Three basic findings were produced by the research:

1. With the exception of purpose, general agreement does not exist among writers on the basic elements of post auditing.

2. The literature has not established a generally accepted set of operating principles to guide the practitioner in the practice of post audit.

3. The literature surveyed, individually or collectively, has not presented an approach to post auditing which is sufficiently structured to enable the practitioner to develop an effective post auditing procedure and to proceed with implementation.

By combining these findings, the study offers the overall conclusion that the charges relating to the inadequacy of present-day literary treatment of post-auditing capital expenditures are valid. 
A SURVEY AND CRITICAL ANALYSIS OF CURRENT LITERATURE ON THE POST AUDIT OF CAPITAL EXPENDITURES

by

Gene Albert Katke

A thesis submitted in partial fulfillment of the requirements for the degree of

Master of Business Administration

Portland State University

1975 
TO THE OFFICE OF GRADUATE STUDIES AND RESEARCH:

The members of the Committee approve the thesis of Gene Albert Katke presented May 16, 1975.

Dr. Leroy A. Gewitt, Chairman

Gr. James R. Bentley

Dr. Emerson Hobgstraat

APPROVED:

Dr. Michael Gaines, Head, Department of Accounting

Dr. David E. Clark, Dean of Graduate Studies and Research

May 16,1975 
TABLE OF CONTENTS

PAGE

CHAPTER

I INTRODUCTION $\ldots \ldots \ldots \ldots \ldots \ldots \ldots \ldots \ldots \ldots \ldots \ldots \ldots 1$

II PURPOSE AND IMPORTANCE OF POST AUDITS $\ldots \ldots \ldots 12$

III SELECTION OF PROJECTS FOR POST AUDIT $\ldots \ldots \ldots .20$

IV FACTORS TO BE POST AUDITED $\ldots \ldots \ldots \ldots \ldots \ldots \ldots .28$

$v$ SOURCES OF POST AUDIT DATA $\ldots \ldots \ldots \ldots \ldots \ldots \ldots .45$

vI TIMING OF POST AUDITS $\ldots \ldots \ldots \ldots \ldots \ldots \ldots \ldots \ldots .54$

VII RESPONSIBILITY FOR POST AUDIT $\ldots \ldots \ldots \ldots \ldots \ldots \ldots 6$

VIII PREREQUISITE ACTIONS $\ldots \ldots \ldots \ldots \ldots \ldots \ldots \ldots \ldots 74$

IX SUMMARY OF FINDINGS $\ldots \ldots \ldots \ldots \ldots \ldots \ldots \ldots \ldots \ldots .82$

BIBLIOGRAPHY ........................... 102

APPENDIX $\ldots \ldots \ldots \ldots \ldots \ldots \ldots \ldots \ldots \ldots \ldots \ldots \ldots \ldots \ldots \ldots \ldots$ 
CHAPTER I

INTRODUCTION

\section{PROBLEM OVERVIEW}

A number of writers in the area of capital budgeting have charged that present day literature on the subject fails to adequately address the post audit phase of capital expenditure programs. Writing in Management Accounting, Carl Hicks, Jr. and L. Lee Schmidt, Jr. have perhaps best sumnarized the concern for this failing with the statement:

Existing literature in the area of capital budgeting is replete with discussions and presentations of the various mathematical and statistical techniques available for determining the investment decision, but yields very little of a descriptive nature concerning the postauditing phase. 1

In a similar statement, Ross Anderson charges:

Reams have been written about how profitable capital expenditures should be planned, but rarely do we read whether the planned profit and return on investment have been achieved. A review of (the) literature leads to the conclusion that authors have been fertile in producing a vast array of literature proposing more and more sophisticated methods for capital expenditure planning. Few business practitioners, if they have been using the proposed methods at all, have managed to measure the results on the same sophisticated basis.

1 Carl F. Hicks, Jr. and L. Lee Schmidt, Jr., "Post Auditing the Capital Investment Decision," Management Accounting, 53, No. 2 (Aug. 1971), p. 24.

2 Ross Henderson, "Improving the Performance of Capital Project Planning," Cost and Management, 45, No. 5 (Sept-Oct. 1971), pp. 33-34. 
Others have termed post audit as "possibly the most neglected aspect of capital investments, ${ }^{3}$ "a practice which still appears to 1 ag behind the other phases of capital budgeting, $" 4$ and "one of the most important, yet frequently neglected aspects in any capital expenditure control program." 5

Finally, in his survey of business practices, James $M$. Fremgen divided the capital budgeting process into three stages: 1) project definition and cash flow, 2) project analysis and selection, and 3) project implementation and review, and concluded that "the literature might better serve practice if it devoted more attention to the first and third stages of capital budgeting." 6

\section{OBJECTIVE}

The objective of this paper is to ascertain the validity of these charges insofar as they relate to the literary treatment of post auditing capital expenditures. More specifically, the study is designed to provide an objective comparison and analysis of present-day writings on post auditing in an attempt to answer the following questions:

3 Robert W. Johnson, Capital Budgeting (Belmont, California, Wadsworth Publishing Co, 1957), P. 147.

4 National Association of Accountants, Financial Analysis To Guide Capital Expenditure Decisions, Research Report No. $\frac{10}{43}$ (1967), P. 84.

5 John L. Montgomery, "Appraising Capital Expenditures," Management Accounting, 47, No. I (Sept. 1965), p. 3.

6 James M. Fremgen, "Capital Budgeting Process: A Survey," Management Accounting, 54, No. 11 (May 1973), p. 25. 
1. Does general agreement exist among writers on what constitutes the basic elements of post auditing?

2. Within each of these basic elements, has the literature established a generally accepted set of operating principles to guide the practitioner?

3. In general, has the literature to date, individually or collectively, presented an approach to post auditing which is sufficiently structured to enable the practitioner to develop an effective post auditing program and to proceed with implementation?

Definition of Technology

The terms Capital Budgeting and Capital Expenditure Program tend to be applied somewhat interchangeably in the literature and indeed seem to have overlapping characteristics by most definitions.

Capital Budgeting. "Capital budgeting is a process of determining how best to allocate a firm's resources to proposed projects, so that optimum benefits will be realized over some future period of time." 7

In broad perspective, capital budgeting includes at least three interrelated steps:

1. Developing a list of potentially profitable projects.

${ }^{7}$ Larry N. Killough, "Planning and Control for Capital Facility Decisions," Budgeting, 16, No. 5 (Mar./Apr. 1968), p. 9. 
2. Determining the funds available for investment.

3. Selecting the most desirable subset from the set of all competing projects.

Capital budgeting, narrowly defined as the capital allocation process, is only a part of the whole system dealing with the rational employment of capital resources in the business firm. 8

Capital Expenditure Program

The purpose of a capital expenditure program is to achieve specific operating or business results, based upon assumptions made with respect to anticipated competitive, economic, and other environmental conditions. The primary measurement of the program's success is the degree to which the planned business
results are actually accomplished. 9 .

A well designed and well executed capital expenditure program must include the following elements:

1. The creative, systematic search for investment opportunities.

2. The measurement of the expected benefits from a specific investment.

3. The comparative evaluation of alternatives.

4. The control of expenditures on approved projects.

5. The post audit of results, 10

The term capital expenditure program will be used in this paper to indicate the total capital acquisition, implementation, and audit process.

8 George A. Christy, Capital Budgeting (Eugene, Oregon Bureau of Business and Education, University of Oregon, 1967),

9 W. R. C. Blundell, "Control of Capital Expenditures," Canadian Chartered Accountants, 92, No. I (Jan. 1968), P. 35.

10 American Institute of Certified Public Accountants, "Analysis For Purchasing and Financing Productive Equipment," Technical Study No. 4 (1967), PP. 3-4. 
of more importance for this study is the critical

difference between two other common terms, Capital

Expenditure (or Project) Control and Post Audit of Capital

Expenditures.

Capital Expenditure Control.

- control over projects from the time approval

is given until the project is in operation (which)

is aided by reports on:
a) physical progress
b) comparison of expenditures versus the capital budget
c) comparison of expenditures versus the appropriations request
d) supplemental appropriations request if required.11

Once an investment project has been approved, and the funds appropriated, it is ready for commitment. Obviously some kind of systematic followup is required to see that the work proceeds on the projected time schedule and stays within the estimated cost. The enforcement of expenditure controls calls for regular progress reports on projects under way. 1

According to Istvan:

controling the relationship between dollars actually
spent in carrying out a capital expenditure project
and the dollars approved for it; as well as a com-
parison of the actual length of time before the
project is in full operation with the period esti-
mated.13

11 C. E. Edge, "Capital Budgeting: Principals and Projections," Financial Executive, 33 No. 9 (Sept. 1965), p. 58.

12 George Terborgh, Business Investment Management, (Washington D. C., Machinery and AIIied Product Institute, 1967), PP. 24-25.

13 Donald F. Istvan, Capital Expenditure Decisions (Indiana University Business Report No. 33, I961), p. I06. 
Post Audit of Capital Expenditures. The function of post audit is also known by several other terms: post mortem, post installation appraisal, measurement after completion, performance audit, post completion audit, post appraisal, and follow-up audit. Regardless of the name used, it can be defined as "a review or evaluation of the operation of a completed capital expenditure project for the purpose of comparing the actual and estimated results of the project." 14

It is reexamination of original estimates in light of actual developments for the purpose of improving methods and procedures of forecasting sales and production costs and secondly, to examine actual costs in detail to find out whether anything can be done to improve them. 15

In his book on capital expenditure decisions, Donald $F$.

Istvan took pains to clearly separate these two terms:

The post audit of capital-expenditure projects must be distinguished from the expenditure control audit. The post audit is not directly concerned with excessive costs of implementation and, as such, does not deal with control of dollar outiays; it is a study made (1) to ascertain the actual performance results (profitability or years to return capital invested); (2) to compare these results with those predicted in the proposal; and (3) to take actiop regarding any differences between the two.16

14 Wandell $\mathrm{J}$. McCorvey, "Auditing the Capital Budgeting Decision," Cost and Management, 43, No. 4 (May-June 1969), P. 30 .

15 John W. Hackney, Control and Management of Capital Projects (New York, John Wiley and sons, Inc., 1965), P. 251. ${ }^{16}$ Istvan, op. cit., p. 38 . 
Post audit of capital expenditures is a relatively straightforward process, once a clear understanding of its purpose and key elements is established. The purpose can be defined as a means of improving our ability to select costeffective capital expenditures by comparing actual operating results (after the expenditure) with original estimates of those results (made during the justification process), to identify areas of weakness which can be improved in future capital projects.

"It is the process of searching out errors" 17 made in the basic estimates and assumptions used in the original justifications so that corrective action can be taken, which would improve the justifications developed for current and future capital expenditures. It does not control capital project costs since it is properly scheduled after the project is completed and made operational. It will determine project profitability, but only from a position of hindsight. It can, however, be used to identify for management, key portions of the project which were part of the original plan, but which were never fully implemented, and are, thereby, reducing the actual return on investment.

Properly used, post audits cause a reexamination of any project which fails to meet performance goals to insure that everything possible is done to make the investment cost effective.

17 Robert E. Caughron, "How We Follow Up Capital Expenditures," NAA Bulletin, 46, No. 7 (April 1965), p. 47. 
LIMITATIONS OF THE STUDY

To keep the study within manageable proportions, certain limitations and parameters have been established. It is recognized for example that the technique of post audit, when broadly defined, has a multiplicity of applications. It is frequently used as a device to measure the past performance of individuals, projects, and systems, and to some degree as a check for completeness on complex projects and systems development. In this study, however, research and discussion is centered around the function of post auditing capital expenditures only.

To simplify the discussion further, the assumption is made that all other aspects of capital expenditures programs such as budgeting, project justification, ranking and selection, the capital appropriation review and approval process, project implementation, and cost control and reporting throughout the implementation phase have been organized and accomplished in some suitable form prior to the post audit phase. Reference is made to these earlier phases where specific actions are required to ensure effective post audits but no attempt is made to formulate procedures beyond that point.

Post audits can be performed by any form of business enterprise to evaluate capital expenditures of all sizes and types. However, to provide a single frame of reference in this discussion, most examples will relate to manufacturing firms and to capital expenditure programs for physical plant and productive equipment. 
As with most management techniques, a number of economic and pragmatic factors would normally be employed to determine the cost effectiveness of performing post audit in any given situation. These considerations are discussed in the chapter dealing with project selection and again in the concluding remarks. This fact notwithstanding, it is necessary to assume that a sufficient number of projects would meet the practical criteria established and that a step-by-step discussion of the post auditing technique is therefore warranted.

\section{RESEARCH METHODOLOGY}

Since the study attempts to bring together for comparison and evaluation much of the currently published material on the subject of post auditing capital expenditures, it can best be described as a descriptive research or survey paper.

The approach here is to define the problem initially but formulate no hypothesis. In place of a hypothesis, the purpose of the study is established in the form of a researchobjective statement. This statement is supported by a series of specific questions (three are used in this study) which are fundamental to and largely formulate the criteria for the objective.

The actual study and analysis of the research material itself, is accomplished using a survey outline consisting of detailed questions designed to extract pertinent information 
from the literature to answer three primary questions. The technique is comparable to a field survey using a questionnaire and was chosen for this study because the subject under investigation is the existing literature as opposed to nonpublished responses normally expected from personal interviews and mail surveys. To interview or survey the authors would have possibly provided more up-to-date views but would not necessarily have confined those views to the published material being evaluated by this paper.

\section{Survey Outline}

Most management techriques are made up of a number of basic elements which are essential for the effective use of that technique. To organize this research project, a preliminary set of elements was developed and used as the survey outline. The elements appear below under the first of the three primary questions supporting the objective statement. Repeating the questions from page 3:

1. Does general agreement exist among writers on what constitutes the basic elements of post auditing?

Element

a) Purpose and importance

b) Project selection

\section{Survey Question}

What is the purpose and importance of the post audit?

Which capital expenditure projects should be selected for audit? 
c) Audit Factors

d) Sources of Information

e) Audit riming

f) Audit Responsibility

g) Prerequisite Actions
Which investment factors should be audited?

From what source(s) can information needed to measure the factors be obtained?

1) When in the life of a project should the first post audit be conducted?

2) Under what conditions is a second post audit required and when should it be conducted?

3) Under what conditions are subsequent post audits required and when should they be conducted?

Who in the organization should have post audit responsibility?

What prerequisite actions are required at the time the original proposal is submitted to ensure effective post audits? 
2. Within each of these basic elements, has the literature established a generally accepted set of operating principles to guide the practitioner? (Review and evaluation of the direction given in the literature for steps above.) Is there a general consensus as to the recommended treatment of each element?

3. In general, has the literature surveyed, individually or collectively, presented an approach to post auditing which is sufficiently structured to enable the practitioner to develop an effective post auditing program and to proceed with implementation? 
CHAPTER II

PURPOSE AND IMPORTANCE OF POST AUDITS

Since the purpose of this paper is to attempt an objective evaluation of the literature available on post auditing, it is important to establish at the outset the degree to which each of the authors surveyed correspond in their definition of the purpose of post auditing. Secondly, the assessment should try to determine how clearly this purpose is communicated to the practitioner, who must apply the principles to the practical realities of business.

One cautionary note may be helpful. For many complex managerial techniques, a simple statement of purpose cannot always be expected to convey the full and complete meaning of the processes involved. In such cases, a detailed study of the mechanics of each individual sub-system is often necessary to gain a thorough understanding of the overall technique.

To establish the type of direction provided by the literature, each author's definition of the purpose of post auditing is summarized below:

Survey Question: What is the purpose(s) and importance of the post audit?

Answer: ${ }^{1}$

4 authors No direction given

1 The total number of responses does not agree with the number of writers surveyed (44) since several offer more than one recommendation. 
36 authors

16 authors

16 authors

6 authors

9 authors

10 authors

4 authors

5 authors

3 authors

4 authors
No direction given

To provide experience which can be used to reexamine the original estimates for the purpose of improving the methods and procedures used and the reliability of future estimates, assumptions, and proposals.

To uncover areas where improvements can be made or where corrective action can be taken to achieve planned results To encourage the collection of sound data in the proposal stage

To make analysts and executives more serious about estimating capital productivity by holding them responsible for them To determine errors made when preparing the original justification as well as reasons for investment failure To stimulate, motivate, or exert pressure on management to achieve the planned results To measure and check on the soundness of management decisions and proposals To determine the real economic justification and profitability of a new investment

To enable management to evaluate the effectiveness of the overall capital 
budgeting program as well as of individual projects

2 authors

3 authors

2 authors

1 author
To improve future investment decisions by using an existing installation as a test case where future investments of the same kind are contemplated To provide management training for younger executives

To identify projects which should be discontinued

To accumulate information and experience which can be used to improve the post auditing procedure

The survey indicater the majority of authors agree in principle that post audit is ueed to evaluate project performance in relation to original estimates. Several authors expand their definitions to describe the specific importance and usage of this information and others suggest a number of additional areas which could benefit from this knowledge.

Excerpts from some of the authors will be used here to illustrate the various directions taken by the literature. Heebink is primarily concerned with the feedback concept:

- . it has long been recognized that control of business and economic matters is dependent on feeding back the results of past decisions to the individuals responsible for them. It follows that postcompletion audits and the feedback principle 
are of fundamental importance in making sound internal investments in plant and equipment.?

Istvan and Montgomery emphasize the educational values of post audit, as does the American Institute of Certified

\section{Public Accountants:}

The post audit is a highly useful tool and, if properly applied as an educational device, has the unique advantage of bringing about its own demise by its power to improve the evaluating abilities of capital planners. 3

The audit provides management with a yardstick for measuring the accuracy of their decision; more importlantly, it promotes control by highlighting problem areas and motivates a more conscientious examination of the facts by $_{4}$ those who participate in the decision to invest."

The value of such a follow-up is primarily educational; if the results predicted in step two have not been realized, a serious error may have been made, and repetition of such errors can only be prevented if management is aware of ${ }_{5}$ its past mistakes and tries to learn from them.

Dean adds to the experience aspect by introducing the measurement of profitability:

Candid and economically realistic postcompletion audits are indispensable incentives for measuring project profitability accurately; they also provide the systematized experience for improving project measurement in the future.

2

David V. Heebink, "Post Completion Audits of Capital Investment Decisions," California Management Review, 6, No. 3 (Spring 1964), pp. 47-48.

3 Donald F. Istvan, Capital Expenditure Decisions, (Indiana University Business Report No, 33, 1961), P. 44.

${ }^{4}$ John L. Montgomery, "Appraising Capital Expenditures," Management Accounting, 47, No. 1 (Sept. 1965), p. 3 .

5 American Institute of Certified Public Accountants, "Analysis for Purchasing and Financing Productive Equipment," Technical Study No. 4 (1967), p. 4.

6 Joel Dean, "Measuring the Productivity of Capital," Harvard Business Review, 32, No. 1 (Jan-Feb 1954), p. 122. 
A number of authors stress the importance of searching our errors made in original assumptions and/or deviations from plan within the project itself. Five such references are listed below to illustrate that once having taken this position, only a few authors go on to suggest that corrective action should be applied to the problems identified.

The statements are ranked beginning with the most vague direction available and ending with the most specific:

The main purpose claimed for checking actual performance against results projected in the investment proposal is to search out the errors made in basic assumptions used in the original project justification.?

The purpose of a capital expenditure programme is to achieve specific operating or business results, based upon assumptions made with respect to anticipated competitive, economic and other environmental conditions. The primary measurement of the programme's success is the degree to which the planned business results are actually accomplished. . and the analysis of reasons for any significant deviations from the plan.8

The purpose of this report is two-fold. The first is to reexamine the original estimates in the light of actual developments for the purpose of improving methods and procedures of forecasting sales and production costs. The second is to examine actual costs in detail to find out whether anything can be done to improve them. 9

7 Ronald E. Myers, "Performance Review of Capital Expenditures," Management Accounting, 48, No. 4 (Dec. 1966), P. 22 .

8 W. R. C. Blundell, "Control of Capital Expenditures," Canadian Chartered Accountants, 92, No. 1 (Jan. 1968), P. 35.

9 John W. Hackney, Control and Management of Capital Projects (New York, John Wiley and Sons, Inc, 1965), P. 251. 
This (searching out of errors) is done by comparing the actual with the predicted results. By making these differences known to the proper people we have been able to make substantial improvements in our current capital expenditure planning program.10

The postaudit is a study made (1) to ascertain the actual performance results (profitability or years to return capital invested); (2) to compare these results with those predicted in the proposal; and (3) to take action regarding any differences between the two.11

Several statements of purpose emphasize the post audit's relationship to project closure:

be impiemented and should subsequently be reviewe
to determine whether the projected benefits have
actually been achieved. Subsequent reviews, or
post-completion audits, at the very least should
improve future investment decision making. More
immediately, such reviews may lead to the rein-
forcement of successul projects and the salvag-
ing of failing projects. 12

(After the) installation has been completed - . the real economic justification for the new facility begins to manifest itself, and is determined by means of a post installation appraisal. To record what experience has been at the project level is the goal of a postinstallation appraisal.13

Post-appraisal on completed projects is essential for the sound control over capital expenditures. The appraisal relates partly to the expenditures but, more importantfy to whether or not the benefits were achieved. 14

10 Robert E. Caughron, "How We Follow Up Capital Expenditures," NAA Bulletin, 46, No. 7 (Jan. 1970), P. 47.

11 Istvan, op. cit., p. 38.

12 James M. Fremgen, "Capital Budgeting Process: A Survey," Management Accounting, 54, No. 11 (May 1973), Pp. 24-25.

13 Philipp W. Binzel, "Economic Justification for Capital Expenditures," The Internal Auditor, (Spring 2965), p. 45

14 C. E. Edge, "Capital Budgeting: Principles and Projections," Financial Executive, 33, 9 (Sept. 1965), P. 48. 
The National Association of Accountants has provided the practitioner with one of the most comprehensive statements of purpose available in a relatively concise form:

A post completion audit, while of ten considered an after-the-fact approach to the control of capital expenditures serves two useful purposes. First, it directs management attention to unsuccessful projects so that additional action may be taken to attain planned performance. Projects that do not immediately meet performance goals are thus given repeated examinations to be sure that everything possible is done to carry the project to fruition. The second purpose served by a definite procedure for following up on project performance is that it tends to preserve the integrity of future capital expenditure requests and justifications. 15

While the brief statements cited above are representative of most of the avialable literature, they fail to do justice to a number of authors who have provided much more comprehensive direction. In the interest of maintaining a reasonable degree of continuity in the text material, excerpts from some of the better articles are included in Appendix I. As previously stated, the majority of authors agree in principle that post audits are used to evaluate project performance in relation to original estimates. One could generally conclude that the literature presents a reasonably consistent basic definition of post audit purpose.

On the other hand, only a few authors elaborate on the specific uses of post audit or recognize that since different capital projects have different purposes, the

15 National Association of Accountants, "The Capital Expenditure Control Program," NAA Bulletin, 40, No. 7 (Mar. 1970), D. 25. 
audits of those projects may have equally different purposes. This makes it necessary for the practitioner to do additional reeearch. Fortunately, those few authors have communicated their information very well and the direction given is quite explicit. 
CHAPTER III

SELECTION OF PROJECTS FOR POST AUDIT

Early in the development of a post audit program the question of scope or project selection must be addressed.

It is necessary to determine what proportion of all new internal investments are to be audited, and if this figure is less than 100 per cent, 1 what the basis for selecting projects will be. ${ }^{1}$

Although the size of a business firm has a definite bearing on the type and magnitude of its capital projects, the corresponding value of auditing those projects, and the physical capability to perform the audits, one would expect the literature to provide some guidance as to a reasonable basis for selecting projects for audit.

To establish the type of direction provided by the research literature, each author's position on project selection is summarized below:

Survey Question: Which capital expenditure projects should be selected for post audit?

Answer:

25 authors

1 author
No direction given or implication that all projects should be audited

All capital projects

1 David V. Heebink, "Post Completion Audits of Capital Investment Decisions," California Management Review, 6, No. 3 (Spring 1964), p. 50 . 
5 authors

Large projects or projects of major significance

1 author Large projects involving major expansions or entry into new product lines

1 author All "savings" or return-on-investment projects

1 author Selected major projects and wherever there is considerable uncertainty

6 authors All large projects and a sampling of small ones

4 authors Projects in excess of a apecified dollar value

From the responses it is evident that more than half the authors writing on post audit felt no obligation to offer the reader help in project $s$ lection criteria and further, did not believe it of sufficient importance to make any specific comments. In contrast, certain authors recognized the significance of project selection criteria and have provided meaningful information.

While, from a practical standpoint, it may not be feasible to determine fund flows for every project, there is no reason why this could not be done for selected major projects, or for projects on which there was considerabie uncertainty. 2

2 Larry N. Killough, "Planning and Control For Capital Facility Decisions," Budgeting 
It should be clear that we should not spend funds to audit all post capital investments. . we must match the anticipated benefits from making better decisions, improving existing projects, or terminating projects, with the costs of post audit. This means we must couple the probability of learning something useful from the audjt with the possible dollar savings involved.

After concluding that auditing all capital projects is

impractical, several authors provide specific suggestions on

which projects should be audited.

Assuming that it is much too expensive to audit all projects, the projects to be audited could be chosen on the basis of size, "key" projects, troubled projects, or at random. Size is probably the best method and all investments over a certain size (depending upon the size of the company) should be audited with only a percentage of those in the middle ranges chosen at random. Some small projects should be audited so that there will always be the chance that any project can be audited. True "key" projects and large projects obviously in trouble should be audited so that costly mistakes can be avoided in the future. ${ }^{4}$

Some companies audit all investments larger than a stipulated amount, e.g., $\$ 100,000$. Other firms have a policy of auditing only certain types of projects, such as those that are intended to reduce costs. 5 Probably a reasonable rule is to post audit all projects over a certain size and smaller projects on a random sample basis. This helps keep the sponsors of small projects honest, while still seeking the larger payoff from reviewing large projects. 6

3 Robert W. Johnson, Capital Budgeting (Belmont, California, Wadsworth Publishing Co., 1970), p. 150.

4 Wandell J. McCorvey, "Auditing the Capital Budgeting Decision," Cost and Management, 43, No. 4 (May/June 1969), P. 32 .

5 Heebink, op. cit., P. 50.

6 Johnson, op. cit., p. 150. 
Commenting on current practice, Istvan, in his survey of industry, indicated that of 24 firms performing post audit the following criteria is employed:

19 post audit all implemented projects

1 post audits only expansion projects

1 post audits only replacement projects

1 post audits only projects over a minimum dollar amount

2 post audit on the basis of a random sample

"These last 5 firms believe that the cost (in man hours) of performing (post audit on all projects) is prohibitive."7

Pflomm also reports on current industry practices:

In general, companies restrict post-completion auditing to capital projects that were proposed and approved on the basis of cost savings or added profits. Projects undertaken for the purpose of improving quality are also audited by some companies to insure that the improvement in product quality was obtained.

Most companies do not attempt to audit all cost savings or profit-oriented projects, but select only those that involve large capital outlays or have major significance to management. Since audits are often time-consuming and expensive, most companies feel they are not warranted in the case of relatively small projects. 8

Pflomm goes on to suggest that some companies with a less formal post audit program select projects for audit on the basis of management request, known trouble areas, or random coverage of operating divisions.

7 Donald F. Istvan, Capital Expenditure Decisions

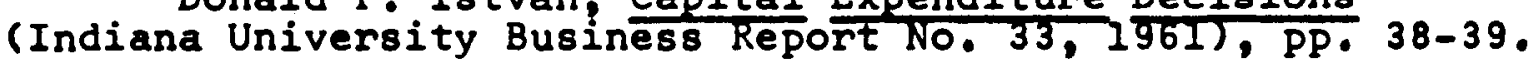

8 N. E. Pflomm, Managing Capital Expenditures (The National Conference Böard Business Policy Study No. 107, 1963), P. 81 . 
Throughout the research, the inadequacy of 8 tandard accounting systems is encouraged as a major barrier to effective post auditing. While this fact is generally agreed to by most writers, the National Association of Accountants takes the position that information provided by well developed cost accounting systems does play a role in determining those projects which need not be audited. Although for many companies this approach could be considered idealistic and therefore of questionable value, it is repeated here to amplify the need for specific criteria in project selection.

In some companies the organization structure and reporting methods are such that management is provided with information which readily reveals the success or failure of new investments. Here there is less need for audit. This is the case when cost centers, standard costs, efficiency measures, cost variance analysis, and product margin measurements run parallel to project and asset classification Under these conditions post audit work can be limited to major projects which are unusual ${ }^{9}$ or cut across organizational lines, $i . e .$, when results are not apparent except by audit or special study.

On the other hand, if management feels that its capital expenditure decision process needs improvement, that project estimates seem loose, and that its past investment record is bad, it may seem it wise to institute a full scope post audit procedure. A full scope approach would be to examine all projects of significant size. 10

9 For an excellent discussion of the impracticality of post auditing research and development or capital projects requiring discretionary or highly managed judgmental expenditures, see Wandell J. McCorvey, op. cit., PP. 30-34.

10 National Association of Accountants, Financial Analysis to Guide Capital Expenditure Decisions, Research Report No. $4 \sqrt{3}$ (1967), P. 86. 
Heebink has perhaps the most comprehensive statement on selecting projects for post auditing.

The practice of giving first attention to large investments is a sensible one from the standpoint of all the purposes of post audits, since the prospective gain from improving future decisions and insuring proper implementation of past decisions is correspondingly large. However, this is not to say that all other projects should be ignored. If it is general knowledge within an organization that only large projects or those of a certain type are post audited, this will preclude the realization of any post audit benefits from the group of excluded projects. Furthermore, it opens the door to the subterfuge of breaking a questionable large investment into amaller segments in order to gain approval more readily and to avoid a potentially embarrassing post audit later.

A more comprehensive approach to selecting projects for auditing is to audit all large ones and a systematically selected sampling of smaller ones. This sample should include:

(A) Projects which are harbingers of possible large future investments

(B) Projects having relatively large prospective savings or incremented profits

(C) A random sampling of other projects regardless of typell

Thus far we have discussed project selection as it

relates to the support of the generalized post audit objectives established earlier in this paper. But it should not be forgotten that post audits are sometimes conducted to accomplish an even more specific management purpose, and that when this is the case, project selection may be determined solely by that purpose. For example, it may be management's desire to measure the effectiveness of current capital investments

11 Heebink, Op. cit., p. 50. 
undertaken for the primary purpose of improving market share. This immediately reduces the field of available projects to only those originally intended for that purpose. When it is not practical to audit all of these projects, further selection might be made on the basis of dollar investment parameters or an appropriate sampling method. By determining the relative success of past projects relating to market share, management should be in a better position to project the potential of similar investments in the future and therefore improve its capital project decision-making ability.

The literature is not explicit on this technique but does suggest that project selection could be based on auditing certain types of projects. References are made to cost saving projects, entry into new product lines, and projects to improve product quality, without specific mention of the advantages to be gained by this type of audit.

One of the most important aspects of selecting profects for post audit is consistently ignored in the literature by all but one writer. That consideration is the critical point that those projects which are to be post audited must be selected at the time of original justification and approval. This is an essential step in post auditing since it is only at this time in the capital expenditure program that the original factors and assumptions, which will be later audited, can be properly identified and documented. 
To quote from Binzel:

In the initial phases of my company's postinstallation appraisal program, the need for better documentation of the original estimates and data accumulation procedures for projects scheduled for appraisal became evident. This pointed up a strong incentive to identify projects scheduled for post appraisal at the time of initial approval. Such a procedure permits arrangements to be made to accumulate revenues, costs and expenses, etc., in sufficient detail in the actual accounts so that they later can be identified and reconciled with the project estimates. 12

12

Philipp W. Binzel, "Economic Justification for Capital Expenditures," The Internal Auditor (Spring 1965), P. 47 . 
CHAPTER IV

FACTORS TO BE POST AUDITED

After the purpose of post audit has been clearly established it is necessary to determine which of the many factors associated with a capital project should be selected for audit. This decision at once defines the scope of the audit and, to a large extent, the degree to which meaningful results will be produced. In effect, the factors selected form the basis of the evaluation and determine, in advance, the potential value or lack of value of the audit to company management.

Since the term "capital investment project" covers an almost infinite variety of types and sizes of projects, it would not be reasonable to expect the literature to prescribe a standard or uniform set of audit factors. Instead, the practitioner would most likely look for examples of factors which could normally be expected to provide measures of project performance and indications of specific deficiencies. The factors presented should also illustrate the number of functional areas from which information must be gathered, (i.e., accounting, marketing, production, engineering, etc.).

To establish the type of direction provided by the research literature, each author's references to audit factors is summarized below: 
Survey Question: Which investment factors should be audited?

\section{Answer:}

16 authors provided no direction. The balance referred

to a variety of factors as shown below.

FACTORS FOR POST AUDIT

(Categorized by Type)

\begin{tabular}{|c|c|c|c|}
\hline $\begin{array}{l}\text { Number of Times } \\
\text { Specificaliy } \\
\text { Suggested in } \\
\text { The Literature }\end{array}$ & Factor & $\begin{array}{c}\text { Unit of Measure- } \\
\text { ment Normally } \\
\text { Used }\end{array}$ & $\begin{array}{l}\text { Normal Source } \\
\text { of Information } \\
\text { (Standard/Advanced) }\end{array}$ \\
\hline \multicolumn{4}{|c|}{ Marketing } \\
\hline 6 & Sales Volume & Units/Dollars & Sales/Inventory \\
\hline 4 & Sales price & Dollars & Sales/Accounting \\
\hline 2 & Sales costs & Dollars & Accounting \\
\hline 1 & Market position & Percentage & Sales \\
\hline 2 & Product mix & Quality/Percentage & Sales/Inventory \\
\hline \multicolumn{4}{|c|}{ Production } \\
\hline 1 & $\begin{array}{l}\text { Maintenance labor } \\
\text { rate }\end{array}$ & Dollar/Hour & Accounting \\
\hline 7 & Labor rates & Dollars/Hour & Accounting \\
\hline 11 & Labor usage & Hours/Unit & $\begin{array}{l}\text { Accounting/Pro- } \\
\text { duction }\end{array}$ \\
\hline
\end{tabular}




\begin{tabular}{|c|c|c|c|}
\hline $\begin{array}{l}\text { Number of Times } \\
\text { Specifically } \\
\text { Suggested in } \\
\text { The Literature }\end{array}$ & Factor & $\begin{array}{c}\text { Unit of Meaure- } \\
\text { ment Normally } \\
\text { Used }\end{array}$ & $\begin{array}{l}\text { Normal Source. } \\
\text { of Information } \\
\text { (Standard/Advanced) }\end{array}$ \\
\hline 2 & Labor flexibility & Qualitative & Production \\
\hline 2 & Tooling Costs & Dollars/Project & $\begin{array}{l}\text { Production/Account- } \\
\text { ing }\end{array}$ \\
\hline 2 & Start up costs & Dollars/Project & $\begin{array}{l}\text { Production/Account- } \\
\text { ing }\end{array}$ \\
\hline $\mathbf{5}$ & Manufacturing cost & Dollars/Unit & Accounting \\
\hline 7 & $\begin{array}{l}\text { Maintenance and } \\
\text { repair costs }\end{array}$ & Dollars/Period & $\begin{array}{l}\text { Accounting/Pro- } \\
\text { duction }\end{array}$ \\
\hline 1 & Supplies cost & Dollars/Period & Accounting \\
\hline 3 & $\begin{array}{l}\text { Rework, scrap, } \\
\text { spoilage }\end{array}$ & $\begin{array}{l}\text { (Dollars/Unit) } \\
\text { (Dollars/Period) }\end{array}$ & $\begin{array}{l}\text { Accounting } \\
\text { Production }\end{array}$ \\
\hline 5 & Utility costs & Dollars & Accounting \\
\hline 5 & $\begin{array}{l}\text { Other operating } \\
\text { expenses (overhead) }\end{array}$ & Dollars/Hour & Accounting \\
\hline 2 & Investment life & Years & Production \\
\hline 1 & Safety consideration & Qualitative & Production \\
\hline 2 & Employee morale & Qualitative & Production \\
\hline
\end{tabular}


Number of Times

Specifically

Suggested in

The Literature
Unit of Measurement Normally Used*
Normal Source

of Information* (Standard/Advanced)
2

3

3

2

9

4

5

1

1
Factor
Qualitative

Factors causing project to fall short of expectation

Corrective action being taken

\section{Materials Management}

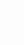

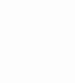

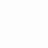

4

Production volume
Production mix
Material usage
Material prices
Vendor services and
procurement results
Obsolescence cost
Inventory cost-
finished goods

Qualitative

Auditor

Auditor

\begin{tabular}{|c|c|}
\hline Units & Inventory \\
\hline Quality/Percentage & Inventory \\
\hline Quantity/Unit & $\begin{array}{l}\text { Inventory/Account- } \\
\text { ing }\end{array}$ \\
\hline Dollars/Unit & $\begin{array}{l}\text { Accounting/Purchas- } \\
\text { ing }\end{array}$ \\
\hline Qualitative & Purchasing \\
\hline $\begin{array}{l}\text { Percentage of } \\
\text { Inventory }\end{array}$ & Inventory \\
\hline $\begin{array}{l}\text { Dollars } \\
\text { (Period Cost) }\end{array}$ & $\begin{array}{l}\text { Inventoryl } \\
\text { Accounting }\end{array}$ \\
\hline
\end{tabular}




\begin{tabular}{|c|c|c|c|}
\hline $\begin{array}{l}\text { Number of Times } \\
\text { Specificaliy } \\
\text { Suggested in } \\
\text { The Literature }\end{array}$ & Factor & $\begin{array}{c}\text { Unit of Measure- } \\
\text { ment Normally } \\
\text { Used* }\end{array}$ & $\begin{array}{c}\text { Normal Source } \\
\text { of Information } \\
\text { (Standard/Advanced) }\end{array}$ \\
\hline 1 & $\begin{array}{l}\text { Inventory cost- } \\
\text { raw materials }\end{array}$ & $\begin{array}{l}\text { Dollars } \\
\text { (Period Cost) }\end{array}$ & $\begin{array}{l}\text { Inventory/Account- } \\
\text { ing }\end{array}$ \\
\hline \multicolumn{4}{|c|}{ Engineering (Manufacturing or Industrial) } \\
\hline 4 & Project description & Qualitative & $\begin{array}{l}\text { Original Justifi- } \\
\text { cation }\end{array}$ \\
\hline 6 & Project objectives & Qualitative & $\begin{array}{l}\text { Original Justifi- } \\
\text { cation }\end{array}$ \\
\hline 2 & $\begin{array}{l}\text { Original justifica- } \\
\text { tion data }\end{array}$ & Quantitative & $\begin{array}{l}\text { Original Justifi- } \\
\text { cation }\end{array}$ \\
\hline 2 & $\begin{array}{l}\text { Original assumptions } \\
\text { and premises }\end{array}$ & $\begin{array}{l}\text { Qualitative } 8 \\
\text { Quantitative }\end{array}$ & $\begin{array}{l}\text { Original Justifi- } \\
\text { cation }\end{array}$ \\
\hline 6 & $\begin{array}{l}\text { Implementation plan } \\
\text { and schedule }\end{array}$ & Calendar dates & $\begin{array}{l}\text { Original Justifi- } \\
\text { cation }\end{array}$ \\
\hline 12 & $\begin{array}{l}\text { Equipment/process } \\
\text { performance (machine } \\
\text { hours/units) }\end{array}$ & Hours/Unit & $\begin{array}{l}\text { Engineering/Pro- } \\
\text { duction }\end{array}$ \\
\hline 10 & Cost savings & Dollars/Unit & $\begin{array}{l}\text { Production/Account- } \\
\text { ing }\end{array}$ \\
\hline 4 & Salvage value & Dollars & Engineering \\
\hline
\end{tabular}




\begin{tabular}{|c|c|c|c|}
\hline $\begin{array}{l}\text { Number of Times } \\
\text { Specifically } \\
\text { Suggested in } \\
\text { The Literature }\end{array}$ & Factor & $\begin{array}{c}\text { Unit of Measure- } \\
\text { ment Normally } \\
\text { Used }\end{array}$ & $\begin{array}{c}\text { Normal Source } \\
\text { of Information* } \\
\text { (Standard/Advanced) }\end{array}$ \\
\hline 3 & Payback & Years & Auditor \\
\hline 3 & Rate of return & Percentage & Auditor \\
\hline 8 & Return on investment & Percentage & Auditor \\
\hline 3 & $\begin{array}{l}\text { Corrective action } \\
\text { recommended }\end{array}$ & Qualitative & Auditor \\
\hline 5 & $\begin{array}{l}\text { Current projection } \\
\text { of future operation }\end{array}$ & Qualitative & Auditor \\
\hline 1 & $\begin{array}{l}\text { Evaluation basis } \\
\text { used }\end{array}$ & Qualitative & $\begin{array}{l}\text { Original Justifi- } \\
\text { cation (Auditor) }\end{array}$ \\
\hline & Quality Control & & \\
\hline 3 & $\begin{array}{l}\text { Product quality con- } \\
\text { siderations }\end{array}$ & Qualitative & Quality Control \\
\hline & Accounting & & \\
\hline 16 & $\begin{array}{l}\text { Amount of capital in- } \\
\text { vestment (broken down) } \\
\text { and variance }\end{array}$ & Dollars/Project & Accounting \\
\hline 12 & $\begin{array}{l}\text { Profit and/or } 1088 \\
\text { of operation }\end{array}$ & Dollars/Period & $\begin{array}{l}\text { Normally not } \\
\text { available }\end{array}$ \\
\hline 6 & Taxes & Dollars/Period & Accounting \\
\hline
\end{tabular}


Number of Times

Specifically

Suggested in

Factor

Unit of Measure-

ment Normally

Used*

Normal Source

The Literature

\section{Factor}

of information

(Standard/Advanced)

\begin{tabular}{llll}
\hline 1 & Depreciation rate & Percentage/Period & Accounting \\
5 & $\begin{array}{l}\text { Depreciation expense } \\
\text { Working capital } \\
\text { (net change) }\end{array}$ & Dollars/Project & Accounting \\
1 & $\begin{array}{l}\text { Insurance cost } \\
\text { Cash flow }\end{array}$ & Dollars/Period & $\begin{array}{l}\text { Normally not } \\
\text { available }\end{array}$ \\
4 & Dollars/Period & $\begin{array}{l}\text { Normally not } \\
\text { available }\end{array}$ \\
3 & $\begin{array}{l}\text { General project } \\
\text { history } \\
\text { General analysis } \\
\text { of project }\end{array}$ & Qualitative & Auditor \\
\hline
\end{tabular}

TOTAL: 227 References (an average of eight factors per author)

* Subjectively assigned to clarify the unit of measure and source of information normally avallable to the Auditor. The sources are shown as standard/advanced to acknowledge varying degrees of sophistication in the record keeping systems of industrial companies. 
From the responses it is apparent that most authors provide a very limited set of examples, and reference would have to be made to many articles to produce a list as complete as the one above. This is unfortunate since it is only through such examples that the author can become sufficiently specific with his message to communicate the full meaning and implications of post audit.

The research, taken as a whole, does provide an indication of the number of functional areas involved in post audit which in turn suggest that audit information must be obtained from a variety of sources (i.e., marketing, materiala, production, accounting, quality control, engineering, etc.). Another significant finding of this survey is that many of the factors used are not normally measured in dollars, further supporting the position that the post audit is much broader than the traditional financial audit.

Although the literature makes only limited reference to specific audit factors, it does offer a number of views on the handling of these factors which are important to the practitioner:

I. Advance Planning is essential to effective post audit The problem is outlined in general terms by Killough:

As in any audit, objectives must be set, and understood by all concerned parties. Certain desirable information simply is not going to be available, and no combination of time, cost and competence is going to produce it. As a first step, 
then, limitations must be determined and goals set in light of these limitations.

A basic objective of the post audit evaluation must be to determine what errors may have been made in original proposals. Unfortunately, because of laxities in planning requirements, a major task in many post audits is to attempt to determine what was originally expected of a project, and the basis for such expectations. I

The National Association of Accountants provides the only comprehensive discussion on the need for advance planning:

Advance planning for post audit work is necessary if it is to be carried out on an efficient and meaningful basis. This point was emphasized several times in this research by those who are directly responsible for the conduct and review of post completion adit studies. Advance planning, in this instance, refers to establishing the original project justification in terms which can be identified and measured in the audit stage. Company experience shows that this "before and after" comparability can be achieved if the basic quantities and dollar measurements are clearly stated in the project analysis. It is also desirable to anticipate the type and form of actual data which will be readily available from future reports. Some suggestions along this line are summarized below.

1. Product sales classifications for both new and existing products should be stated in the project plan in the same way as they are expected to appear in future sales and margin reports.

2. Data for production units, labor hours, machine hours, and material quantities should be defined in terms which are consistent with company definitions and production reporting methods.

3. Dollar figures for profit increments cannot be analyzed satisfactorily at a later stage unless the basic measurements for prices, product quantities, wages, hours, and the like are identifiable.

1 Larry N. Killough, "Planning and Control for Capital Facility Decisions," Budgeting, 16, No. 5 (Mar/Apr 1968), P. 14. 
4. If the company plans to change its accounting reports between the project analysis stage and the later implementation stage, such changes should be anticipated if possible.

5. Cost savings which depend upon changes in both 8 tandard costs and variances must be developed so that subsequent standard cost and variance data can be related to the project plan.

6. Asset classifications in project proposals need to be stated in terms which are suitable for both project cost control and the plant asset accounts that will be recorded upon project completion.

7. If the project envisages a change in variance costs such a change should be distinguished, in the project, from a planned increased commitment for fixed costs. This distinction is important because when operations start, a change in fixed cost commitment may be more lasting than a change in variable costs. A clear understanding of these elements is a necessary part of the analysis of project performance. ${ }^{2}$

II. A post audit should concentrate on significant and basic factors which determine the success or failure of a project:

Identification of the "key" factors underlying the success of each individual project should be of paramount importance to an effective post audit. This element is discussed by the literature but again only in a very general way. Heebink has provided perhaps the best discussion of this critical element:

2 National Association of Accountants, Financial Analysis To Guide Capital Expenditure Decisions, Research Report No. $\sqrt{3}$ (1967) PP. 89-90. 
It is preferable to select the elements of particular significance in the original study and audit these with care, even if this means that only a superficial check can be made of items of less importance. For example, if a new machine were expected to pay for itself largely from direct labor savings, the audit should be primarily concerned with ascertaining the validity of the estimate of direct labor cost with the machine in operation. Secondary attention should be given to such things as quality, maintenance costs, and indirect labor; if these items are roughly in accordance with expectations, there is very little to be gained from auditing them in great detail. It is desirable to investigate both quantitative and qualitative aspects of a project's performance. . .sometimes an historical payback or return figure is calculated as part of a post audit. There is nothing wrong with this; indeed, it may be of academic interest to various people. However, there is little practical value to be gained from this exercise. It is, after all, the validity of the original estimates and the assumptions underlying them, not the computation of the investment "yardstick" used, that is of interest in an audit. Historical rates of return are of little help in improving either future estimates or the implementation of past decisions. 3

The following comment from Killough more closely illus-

trates the literature's lack of direction:

While it is realized that another objective must be to compare actual figures with projected figures, in no case should the audit be simply an attempt to compare historical results with original projections. Practically speaking, it may never be possible to compare actual and projected discounted cash flow rates, and even if it is possible it cannot be done until the useful life of the project has expired. For this reason it is considered much more important to attempt to continually update original data in light of existing conditions and to use this information to control current operations and enhance management's ability to plan effectively in the future. 4

3

David V. Heebink, "Post Completion Audits of Capital Investment Decisions," California Management Review, 6, No. 3 (Spring 1964), PP. 50-51.

4 Killough, op. cit., pp. 14-15. 
III. The audit must evaluate project characteristics using the same basis as that applied to original justification data

A number of authors have offered reasonably clear direction on the necessity for compatability of the basis of evaluation between the original proposal and actual performance. Two examples illustrate this direction:

The types of information sought in the post audit are directly dependent upon the information employed in making the original proposal and reaching the decision for approval. In 13 firms the information collected during the post audit is presented in a form that is identical, or nearly so, with the form used to submit the original proposal. The remainder of the firms use a slightly modified form that provides space for the comparative analysis of the 5 actual results with those originally estimated.

In preparing the report, "actual" values should be established on the same basis as was used in preparing the original appropriation request. In particular, operating costs must be established on an incremental basis, and will usually differ from the conventional operating costs reported for dayto-day control of the efficiency of operations.

IV. Two schools of thought exist on the value of using judgmental as well as factual (quantifiable) data in the post audit

A. The factual position is stated by Kemp:

To the extent that the actual investment and operating results can be objectively determined, they should be compared with the corresponding items forecast in the proposal.

5

Donald F. Istvan, Capital Expenditure Decisions (Indiara University Business Report No. 33, 1961), Pp. 40-41.

6 John W. Hackney, Control and Management of Capital Projects (New York, John Wiley and Sons, Inc., I965), p. 249. 
In order for the comparisons of actual and forecast investment and operating results to be really informative and useful, they must be reliable. Their reliability depends basically upon the reliability of the actual investment and operating data entering into the comparisons. Some actual data are available; some are unavailable; and some are non-existent. Judicious selection of the actual items to be compared with the corresponding forecast items is necessary to ensure reliable comparisons.

As a general proposition, the actual items must really be actual, that is, objectively determinable. Comparisons of two sets of estimates--the proposal estimates and estimated "actyal" data-yield results of questionable reliability.

B. A larger number of authors prefer a combination of

factual and judgmental elements:

In addition to financial and economic yardstick comparisons, the appraisal should include evaluations of performance with respect to market position, productivity, flexibility, product quality improvement, safety, etc., when such indicators were used in the original justification of the project. In some of these areas, the appraisal can be only judgmental, however, this does not necessarily detract from its value. Project estimates must not be limited to items which can be precisely verified later. The requirements for later appraisal should not dictate the factors to be included in the original evaluation; however, it is wise to consider
them during the evaluation phase.

Matthews reports similar findings:

My study revealed a rather striking inconsistency between theory and practice. To evaluate the over-all financial success of a capital expenditure, executives need a combination of cost and revenue analyses. Yet, while all 12 fims use detailed accounting procedures to get good cost data, only half of them attempt to evaluate the revenue performance of projects.

1

Patrick S. Kemp, "Post-Completion Audits of Capital Investment Projects," Management Accounting, 47, No. 12 (Aug. 1966), PP. 49-50.

8 Philipp W. Binzel, "Economic Justification For

Capital Expenditures," The Internal Auditor, (Spring 1965), p. 47. 
I realize, of course, that the success of some types of capital expenditures (for example, expenditures dealing with safety and morale or even with products added for the strategic purpose of rounding out a line) cannot be measured easily or directly by cost and revenue yardsticks. Some projects need to be judged in other ways, and a performance review system must be capable of applying evaluative criteria that are relevant to the type of investment decision initially made. But this does not negate the principle of comparing costs and results. 9

v. The audit should be tailored to the firm and the specific project in question

The technique of tailoring audits to meet the unique characteristics of individual projects is an important consideration to the practitioner. Three authors have made worthwhile comments in this area:

Post-completion audits vary substantially in form and content, depending upon the nature and complexity of the projects involved. Less than half of the companies reporting on the point use standard forms. Most prefer to prepare each post audit in the fashion that best lends itself to the project being audited. Some firms observe that the principal content, the explanation of variances from the forecast results, is best expressed in narrative form.

Post completion audits usually contain the following basic information:

Number of the approved appropriation request Location (plant, division, or operation) that requested the appropriation

Purpose of the project

Amount authorized

Amount actually expended

Estimated savings and/or return on investment Actual savings or return

Reasons for variations

Signatures of those who prepared and/or reviewed the post audit

9 John B. Matthews Jr., "How to Administer Capital Spending," Harvard Business Review, 37, No. 2 (Mar/Apr 1959), p. 95. 
Some of the above information is purely for purposes of project identification and is presented very briefly. However, some firms require breakdowns of expenditures and savings, both estimated and actual, similar in the amount of detail to that required in the original appropriation request. For example, the post audit procedures of a diversified manufacturer require estimated versus actual savings or profit improvement broken down by material, direct labor, indirect labor, fringe items (applicable to labor), maintenance and repairs, supplies, property taxes and insurance, depreciation, utilities, scrap and rework, and other items as applicable. Costs as originally estimated are adjusted for any wage and material cost differential that may have occurred subsequent to the original estimates, and are compared with actual costs on an annual basis.

Companies also frequently require considerable detall on the reasons for variances between forecast and actual benefits. Most commonly, explanations for variances involve changes in equipment prices, labor costs, material costs, or sales volume, as well as outright mistakes in estimates or calculations in original proposals.

In addition to the basic information, post-completion audits often contain other data, sometines specified (especially in the case of companies with standard forms and procedures), sometimes furnished at the discretion of the post auditor if he considers it helpful or necessary to a complete understanding of project performance. Such information is variously reported to include:

Estimated versus actual project completion dates, with explanations of delays

Explanations of project cost overruns Action being taken to correct deficiencies Future prospeets (for projects ourrently failing) Details of equipment performance Details of procurement and vendor service Comments on the adequacy of local accounting records needed for making a post auditlo

10 N. E. Pflomm, Managing Capital Expenditures (The National Conference Board Business POIicy Study No. 107, 1963), Pp. 83-84. 
In the final analysis, the information sought in the post audit, like the information needed for sound decision-making on original proposals, must be tailored to be the specific nature of the individual firm and its management. 11

VI. Narrative reports are of real value to management

A statement concerning the following considerations should also accompany the accomplishment report by way of amplification:

1. Review of objectives

This should be a statement outlining the prior facilities and comparing these facilities in narrative form with the new facilities stating the objective which was expected to be accomplished and the prospective savings.

2. General comments on conditions existing during the first year

This may be sort of a historical sketch of the progress made in the first full year of operation, giving date the new facilities were put into use, the price fluctuations in materials used, production level as compared with estimate, and any other pertinent facts, especially costs incurred which may not have been anticipated in the forecast.

3. Future outlook

Shown here may be a statement of what is expected from the project in the future, taking into account expected plant production level, price and wage rate changes anticipated, and any other factors which might influence the costs absorbed by the project. After giving full consideration to these factors, an estimated future yearly savings in operating costs should be shown along with a return on investment calculation. Any management is interested in knowing what is expected of its projects in future years, especially where these projects are planned on a return-on investment basis.12

11 Istvan, op. cit., p. 41.

12 Arthur V. K. Deekens, "Did We Realize on That Capital Outlay?" NAA Bulletin, 40, No. 9 (May 1959), Pp. 87-88. 
To sumarize, the literature could have given the practitioner far better direction in the selection of factors to be post audited. It was recognized at the beginning of this chapter that one would not have expected any author or group of authors to produce a standard set of factors because of the variety of capital projects suitable for post audit. This, however, should not have prevented the literature from developing basic guidelines on the selection and use of audit factors.

At least three areas should have received more attention:

1. Each author should have suggested a sizeable range of factors to illustrate both the type and source of information commonly required by the audit.

2. More emphasis should have been placed on the importance of basic factors as opposed to broad measures which are derived from those basic factors. For example, since it is the production rate of a machine which ultimately determines operating cost, product cost, return on investment, etc., most of the audit effort should be applied to measuring this factor rather than the subsequent arithmatical steps commonly specified. This circumstance leads to the third area of concern.

3. Every capital project is subject to internally controllable factors as well as to those outside the control of the business firm. In addition, there exists within each project certain basic 
factors which are key to the success of that project. These "key" factors are often different for other projects and must be identified at the time of project justification. The success or failure (or some degree in between) of each individual project is directly dependent upon achievement of performance estimates for certain "key" factors. Consequently, the auditor will want to identify any external factors which did not materialize as forecasted, but should give primary attention to the "key" controllable factors which are not performing to expectations. These (internal) factors are subject to corrective actions which can be applied to improve ovenall project performance. 
CHAPTER V

SOURCES OF POST AUDIT DATA

An important element in structuring a post audit program

is that of identifying, and when necessary, making provision

for the source(s) of information used in the measurement of

each factor being audited.

If post audit is used, where will the data and information come from? Accounting records are generally not set up to report on individual projects. A special study, using the accounting records, may be expensive and time consuming. Furthermore, the problem of isolating the effects of a given investment project may make followup impracticable. What is the effect, for example, of the improvement of one product on the sales of other products handled by the company? What is the source of this sort of data?

Performance reviews permit the evaluation of actual performance by determining the extent to which proposals have achieved the results projected for them. The question is whether the original assumptions, policies, and analyses used in individual decisions have proved sound and well conceived in terms of actual results. Performance review is thus much broader than an accounting review that seeks only to determine wether project costs have exceeded cost estimates. 2

This concern, for one of the major barriers to a post audit program, is expressed by several authors. The National Association of Accountants states the problem as follows:

1 Robert K. Jaedicke, "Rate of Return Verification By Followup," NAA Bulletin, 41, No. 10 (June 1960), p. 64.

2 John B. Matthews Jr., "How to Adminster Capital Spending," Harvard Business Review, 37, No. 2 (Mar/Apr 1959), p. 95. 
A significant obstacle to the establishment of a post-completion audit plan is the difficulty of obtaining actual performance figures to compare with estimates made in the budget or justification.

To establish the type of direction provided by the research literature, each author's position on the sources of audit data is sumnarized below:

Survey Question: From What Source(s) Can Information Needed To Measure The Audit Factors Be Obtained?

Answer: ${ }^{4}$

30 authors

Problem not discussed. No direction and/ or implication that existing accounting records provide adequate data

6 authors Acknowledge the problem but give no direction

6 authors Recommend cost collection on a project basis through the use of parallel or special accounting systems

3 authors Recommend use of special studies designed specifically to obtain data about individual projects.

The majority of authors fail to discuss the problems surrounding the sources of post audit information, suggesting a lack of awareness of such problems or an inability to

3 National Association of Accountants, "The Capital Expenditure Control Program, NAA Bulletin, 40, No. 7 (Mar. 1970), P. 25 .

4 The total number of responses does not agree with the number of writers surveyed $(44)$ since several offer more than one recommendation. 
provide workable solutions to them. Either way, it is considered a serious omission, implying to the practitioner a simplicity which does not exist.

Where the problems are recognized, the arguments are substantial and emphatic. Unfortunately, most authors acknowledging the inadequacy of accounting records for post audit purposes offer little in the way of constructive alternatives.

Information retrieval of actual results must be considered a problem of the first magnitude since traditional accounting systems are not designed to supply such information, yet, this information may well be an important link in the overall corporate evaluation process.

It is difficult to prepare these (operating performance) reports. As mentioned before, the project economics must be viewed in exactly the same way as they were when the estimates were prepared, which usually means that conventional accounting figures made up on a routine basis cannot be used directly. 6

The use of parallel (accounting) systems is frequently suggested as a possible solution. Hicks and Schmidt in proposing their computerized approach to post audit conclude that:

In essence the company is able to run a parallel system, one on a period basis, the other on a project basis. By coding all accounting entries.. the company is able to maintain cost control on a project basis, and with proper identification as

5 Larry N. Killough, "System Framework For Capital Expenditure Program Development," Management Accounting, 52, No. 4 (Oct. 1970), p. 31 .

6 John W. Hackney, Control and Management of Capital Projects (New York, John Wiley and Sons, Inc., 1965, P. 251. 
to the coding of a particular capital project, relevant accounting data can be retrieved for variance analysis.7

According to McCorvey, "the present accounting system can be modified to collect costs on a project basis or. . a parallel system might be installed to collect the needed data. 18

Establishing and maintaining separate project cost records is also supported by both Heebink and Pflomm:

Fortunately, there is an alternate approach which is often less troublesome. It consists of recording costs and income attributable to the project in temporary accounts during the time that post audit information is being collected. 9

One suggested means of overcoming this problem is to have central accounting determine in advance which projects will be audited, and advise the local accounting units concerned what records they should keep. Another solution adopted by some companies is to maintain cost and income records by project until post audits are completed.10

In Chapter IV a significant number of operational-type performance factors were identified as essential to the post audit. Clearly, this indicates the need for obtaining nonfinancial as well as accounting data.

7 Carl F. Hicks, Jr., and L. Lee Schmidt, Jr., "Post Auditing the Capital Investment Decision," Management Accounting, 53, No. 2 (Aug. 1971), p. 25.

8 Wandell J. McCorvey, "Auditing the Capital Budgeting Decision," Cost and Management, 43, No. 4 (May/June 1969), p. 31 .

9 David V. Heebink, "Post Completion Audits of Capital Investment Decisions," California Management Review, 6, No. 3, (Spring 1964), p. 51.

10 N. E. Pflomm, Managing Capital Expenditures (The National Conference Boara Business Pol Icy Study, No. I07, Dec. 1966), P. 95 . 
In addition to financial and economic yardstick comparisons, the appraisal should include evaluations of performance with respect to market position, productivity, flexibility, product quality improvement, safety, etc., when such indicators were used in the original justification of the project. 11

Nevertheless, many authors persist in seeking only accounting data, be it traditional in nature or related opecifically to an individual project. For example:

Performance review is resisted in many instances because executives consider this review function an unnecessary duplication of effort, that is, the conventional accounting reports are considered an adequate basis for evaluating capital expenditure programs. However, accounting in its usual form is not wholly suitable for evaluating the results of investment decisions and of capital budgeting performance for the following reasons:

1. Accounting on an accrual basis is inconsistent with the cash basis used in capital budgeting.

2. Accounting asset measurements may not give the true picture of economic costs and revenues necessary for capital budgeting systems.

3. Accounting is concerned with discrete periodic intervals of time for measuring income, whereas results from capital investment projects rarely correspond to accounting periods.

4. The entity approach emphasized in accounting methods is made up of many intermingled capital investments initiated at various previous times so that we are not able to see the various investment projects separately. 12

11 Philipp W. Binzel, "Economic Justification for Capital Investment," The Internal Auditor, (Spring 1965), P. 47.

12 Ronald E. Myers, "Performance Review of Capital Expenditures," Management Accounting, 48, No. 4 (Dec. 1966), PP. 21-22. 
In a similar report, Horngren mentions only financial data:

The accounting method usually facilitates followup because the same approach is used in the forecast as is used in the accounts. Yet exceptions to this ideal often occur in the accounting method. The most common example of exceptions would be the inclusion in the forecast of initial investment of some items that are not handled in the same manner in the subsequent accounting records. 13

Johnson, in discussing the evaluation of projects by

projected cash flows, also confines the discussion to financial data:

Unfortunately, accounting records are not kept on this (project) basis, so a post audit requires that the accounting data be transformed from the accrual to the cash system. This is especially important on major investments. Under SYD and other forms of accelerated depreciation, the profit figures in the early years of a project may look very gloomy. But in fact the cash flows may be equal to or better than those anticipated in the original estimates. In addition, data may not be stored by project, so that it is difficult to sort out the incremental cash flows attributable to a particular investment. 14

Unfortunately, in the process of recognizing the problem, the literature continues to mislead the practitioner by concentrating almost totally on the need for financial data, with seemingly little regard for other performance factors which are basic to a comprehensive (and meaningful) post audit. One exception to this is found in the survey

13 Charles T. Horngren, Cost Accounting, A Managerial Emphasis (Englewood Cliffs, N. J., Prentice haIl, Inc., I955), p. 418.

14 Robert $W$. Johnson, Capital Budgeting (Belmont, California, Wadsworth Publishing Co., I970), P. I49. 
conducted by Dean in which the need for a separate recordkeeping system is emphasized without a restriction to accounting data:

On another one third of the audited projects (surveyed), the available data were found to be inadequate to the task of checking on the original estimates. This points up the need for a system of record keeping which will permit competent post completion audits. Is

A somewhat more enlightened proposal is that the necessary audit data be obtained by conducting a special study on each project involved.

In the majority of instances, the chart of accounts or an existing regular report will not yield the detailed data necessary. Offsetting factors, such as volume changes, price increases, new union agreements, etc., may hide the actual results obtained by the capital project. The post completion audit thus requires a special study for ${ }_{16}$ each project to secure the necessary figures. 16

Even if the audit is confined. . to a comparison of the realized and predicted project performance (with no second-guessing of the estimates of what would have been without the project), it is still necessary in most cases to go beyond the regular accounts. These are rarely set up by projects. Part of the data must come from the work sheets of the original project analysis. It is there that the forecasts of performance are found which it is the purpose of the audit to check. The other part must come, of course, from examination of the performance actually realized. Like the original estimates, this analysis must rely mainly on special studies.17

15 Joel Dean, "Measuring the Productivity of Capital," Harvard Business Review, 32, No. 1 (Jan/Feb. 1954), P. 122.

16 National Association of Accountants, "The Capital Expenditure Control Program, NAA Bulletin, 40, No. 7 (Mar. 1970), P. 25.

17 George Terborgh, Business Investment Management, (Washington D. C., Machinery and Allied Products Institute, $1967)$, p. 255. 
This approach while still predominantly financial in nature, begins to recognize the need for other types of audit information.

To summarize, present day literature generally does not recognize the problems associated with obtaining post audit information. Where such recognition is given, it is discussed mainly in financial terms and to this extent misleads the practitioner into believing that this is the only type of data required by the audit. Two alternatives to the use of traditional accounting systems have been offered:

1. Use of a second accounting system which parallels the main procedure and attempts to isolate relevant costs pertaining to a specific project.

2. Use of special studies designed to gather project information on an incremental basis specifically for the project(s) being audited.

In practice, the information required by a post audit varies with the type of project involved, the factors to be measured, and with the objectives of that project. Most projects must be measured by a combination of financial and operational data too extensive and diverse to be collected by any single system. Parallel or separate systems would normally be considered too limited and much too costly to support a post audit program. 
The proposed use of special studies recognizes the unique informational needs of post audit but fails to suggest by what means the information will be collected and stored prior to being gathered by the study. The approach does imply that post audit is best accomplished by the use of individual measures instead of systems of data collection. If one assumes that prior arrangements are made to structure the collection of information on specific measurements, the special study method would seem to come closest to accomplishing the audit objective in a cost effective manner. 


\section{CHAPTER VI}

\section{TIMING THE POST AUDITS}

As with any scientific measurement, a good deal of thought needs to be given to selecting the proper time in the life of a project to conduct a post audit. No less important, is the question of whether more than one audit is needed to accomplish the objective.

The objective of post audit (repeated from Chapter I) is to improve our ability to select cost-effective capital expenditures by comparing actual operating results with original estimates of those results, to identify areas of weakness which can be improved in future capital expenditures. Properly used, post audits cause a reexamination of any project which fails to meet performance goals to insure that everything possible is done to make the investment cost effective.

To establish the type of direction provided by the research literature, each author's position on post audit timing is summarized below:

Survey Question: When in the life of a project should the first post audit be conducted? 
Answers: 1
A) 18 authors
No direction given
B) 4 authors
When project is completed and begins operation

C) 4 authors

After project has been operative for an appropriate or reasonable period of time

D) 4 authors

During the first year project is put into normal operation

E) 6 authors

After project has had an opportunity to shake out operational bugs and is operating at its apparent full capability

F) 8 authors At the end of the first year of operation

6) 1 author After project has been in operation for several years

H) 1 author Only after project is operating at the level indicated in the proposal

Survey Question: Under what conditions is a second post audit required and when should it be conducted?

Answers: ${ }^{2}$

A) 29 authors

Condition

No direction given No direction given

B) 2 authors

None

On a periodic basis

C) 1 author

None

Continually after initial audit

1 The total number of responses does not agree with the number of writers surveyed (44) since several offer more than one recommendation.

2 Ibid. 
Condition

D) 1 author

E) 2 authors

F) 1 author

6) 1 author

H) 1 author

I) 1 author

J) 1 author

K) 2 authors

L) 1 author

M) 3 authors
None

None

None

None

None

Large expansionary projects

If followup is

"necessary"

Project does not

meet expectations

Long life projects

Project does not

meet expectations
Timing

3 months after

facility is in

operation

One year after

start up of pro-

duction

At set annual

intervals

At end of second

year of operation

At end of fifth

year of operation

Continually after

project completion

At end of first

year of operation

At end of second

year of operation

Selected year

after operation

As scheduled 
Survey Question:

Answers: 3
A) 30 authors
B) 2 authors
C) 1 author

D) 1 author

E) 1 author

F) 1 author

G) 1 author

H) 1 author

I) I author
Condition

No direction given

None

None

None

None

None

None

\section{Timing}

No direction given

On a periodic basis

Each quarter the

project is in operation

End of each year

for the life of

the project

At set annual

intervals

As scheduled

Continually until

project has achieved

a steady state of

peformance

End of each sub-

sequent year

Two years after

start up of project

3

Ibid. 
Condition

J) 1 author

K) 2 authors

L) 1 author

M) I author
Long life project

Project does not

meet expectations

Large expansionary

project

Large project
Tining

At selected year

after project

start up

As scheduled

Continually until

a part of the

regular accounting

system

Continually until

cash flow exhibits

some stability

A major cause for the widely divergent guidance of fered by the literature is the fact that the nature of the project itself determines to a large degree the most appropriate timing. Writers may be tempted to generalize in an effort to include all types of projects under one rule. Nevertheless it must be concluded that if a practitioner made such a survey, the result would be utter confusion. One would be better advised by concentrating on the few authors offering pertinent comments on the subject of timing. Jaedicke believes an early audit is necessary. Post audit may wall be most valuable during the "debugging" period. The purpose of such an audit is more to facilitate complete installation and 
help work out technical problems than to verify the return on the project. In order to assess the return, it is probably necessary to audit at least one operating period beyond the date on which installation and preliminary testing have been completed. 4

Heebink counters that early audits are inadvisable.

Premature audits are not a realistic basis for taking corrective action with respect to either project implementation or future capital investment decisions. On the other hand, if too much time lapses, the opportunity cost of delayed corrective action may be substantial.

Other authors support the latter position.

They (operating performance reports) cannot be prepared immediately upon project closing, because normally neither the market nor the operating costs have become stabilized by that date. Usually a tentative report is prepared six months after first production, with a followup at one year and another at the end of the second year if profitability conditions continue to change or if return is not developing as well as expected.6

Baker writes that "since the early life of an invest-

ment is most important, it is advisable that the post audit be performed after the first year." He goes on to say, "on projects with long lives, an audit may be performed several times the first year, the fifth year, and the tenth year, for example. ${ }^{7}$

4 Robert K. Jaedicke, "Rate of Return Verification By Followup," NAA Bulletin, 41, No. 10 (June 1960), p. 63.

5 David V. Heebink, "Post Completion Audits of Capital Investment Decisions," California Management Review, 6, No. 3 (Spring 2964), p. 49.

6 John $W$. Hackney, Control and Management of Capital Projects (New York, John Wiley and Sons, Inc., 1965), P. 249.

7 Kenneth A. Baker, "Management Reviews Capital Expenditures," Budgeting, 14, No. 3 (Nov. 1965), pp. 16-17. 
According to a National Industrial Conference Board study,

\begin{abstract}
- . about half of more than thirty companies having a post audit program reported that they perform the first audit one year after the completion of a project; however, practices ranged from auditing immediately upon completion to waiting until the end of a project's payout period. Other surveys have produced similar information. It has also been found that most concerns do not repeat an audit once a project has been determined to be performing satisfactorily, al though practice on this score varies too.
\end{abstract}

As a practical matter, few if any newly acquired assets are able to perform to optimum levels immediately after being placed in service. Johnson recognizes the time value of capital dollars in the following statement:

The timing of a review also involves a trade-off of benefits. A post audit is not appropriate until the new machine or plant has reached a steady state or a level of the learning curve so that no further large shifts in productivity are likely. Then, as time goes by, the certainty of being able to identify the project as a success or failure increases, with the ultimate perspective being at the termination of the project. But by waiting for a post audit, we are diminishing the present value of the lessons to be gained from the audit. Consequently, the post audit should occur when the benefits to be gained from a more definitive appraisal are outweighed by the returns to be derived from improved future decisions and possible correction of deficiencies in the existing project. The concept may be neatly expressed, but it is obviously difficult to implement. 9

8 N. E. Pflomm, Managing Capital Expenditures, The National Conference Board Business Policy Study No. 107 (1963), Pp. 81-82.

9 Robert $w$. Johnson, Capital Budgeting (Belmont, California, Wadsworth Publishing Co., 1970), p. 150. 
Only one writer, McCorvey, discussed the possible effects of seasonality on project performance. This factor is particularly important when product sales and production volume directly effect plant or machine operating efficiency, and is an obvious consideration when the capital project itself involves new product introduction.

Reporting on his survey, Istvan gives perhaps the most misleading direction found in the research.

The post audit is usually undertaken during the first year that the project is put into normal operation. All 24 firms using the post audit make it only after the project is operating at the level indicated in the proposal. Io

This implies that as long as the project fails to reach the operating level originally estimated, no audit should be conducted, a proposition which is difficult to understand.

Probably the most straightforward direction for the timing and frequency of post audits is provided by Terborgh:

There is no hard and fast rule for the timing of post audit, but obviously the most logical point is at the end of the period for which the performance of the project has been estimated - . certainly you do not want to audit before the project has shaken down and is developing its full capabilities. In some cases this will not require a whole year. For simple projects, quickly seasoned, you can often proceed sooner. For complex projects with long break-in periods, on the other hand, you may have to wait two or

10 Donald F. Istvan, Capital Expenditure Decisions, (Indiana University Business Report 10. 33, I961), p. 40. 
three years before the verdict is obtainable. Since audit is always instructive and frequently beneficial to subsequent operations, there is no point to unnecessary delay. The only general rule we can suggest is to do it as soon as reasonably conclusive results can be had.

Ordinarily, a project will be post audited only once. If the audit discloses serious deficiencies relative to the estimated performance however, and if these deficiencies are deemed curable, you may want to follow with a second checkup after the cure has been tried. Occasionally there may be more. Il

It is possible that those who suggest audits on a regular, or period basis, or on the basis of cash flow, regular accounting records, or annual periods, may be preoccupied with the notion that post audits are inseparably tied to traditional accounting methods and data. Yet as was pointed out in Chapter $V$, the basic audit data necessary for project evaluation generally cannot be found in today's accounting systems and in fact comes mostly from operational records and other record keeping systems put into effect specifically to support the audit. This is not to suggest that regularly scheduled monthly or quarterly cut-off periods are not used for the data involved. It is emphasized simply to establish the point that post auditing is not routine accounting and should not be treated as such.

There is perhaps an even more important consideration in the timing of the post audit which has not yet been mentioned. This consideration is the proposition that initial

11 George Terborgh, Business Investment Policy (Washington D. C., Machinery and AIIied Products Institute, 1958), PP. 244-45. 
post audit timing must be established during project justification and is virtually dependent upon the implementation schedule used in that justification.

If we accept our original statement of the purpose of post audit, it is apparent that the timing of the audit is a critical part of its effectiveness. It is the point at which we measure actual results and compare them with expectations to determine project performance. In Chapter IV, we discussed the many factors that make up project performance, not the least of which was the calendar time the project was projected to be fully operational. How then can we expect a post audit to measure this performance if the timing of the audit is not established at the time of original project justification, to coincide with the projected performance date?

This point is of particular importance to management when the project in question, having missed its scheduled completion date, begins to increase company costs.

The cost of being late with satisfactory project performance can be a serious consideration in at least three separate situations:

1. Loss of revenues while continuing to incur increased operating costs beyond a planned implementation date (generally experienced in most if not all types of capital projects). 
2. Loss of production capability to support marketing efforts to capitalize on, or exploit a particularly seasonal market or advantageous product introduction time frame.

3. Failure to meet performance deadines where penalty contracts are involved.

In my view, the literature as a whole is remiss in failing to recognize and place emphasis on this crucial point. Bowman and McCorvey are the only authors surveyed who bring out the fact that the proper time to establish the audit date is "at the time the proposal is submitted for management approval"12 or, "at the time the investment is approved."13

In summary, a post audit can be a one-time effort or can involve several reviews, depending upon the nature and success of each project. Audits conducted prior to the time each project is completed and fully operational should be regarded as a part of the firm's capital expenditures (project) control program and should not be confused with post audit which is an after-the-fact appraisal. This distinction is necessary if we are to separate individual project responsibility from overall management review, but as a practical matter a firm may wish to combine the two activities into a single review schedule, keeping in mind the timing criteria required by each.

12 Keith J. Bowman, "We Follow Up Our Capital Outlays," NAA Bulletin, 39, No. 7 (Mar. 1958), p. 92.

13 Wandall J. McCorvey, "Auditing the Capital Budgeting Decision," Cost and Management, 43, No. 4 (May/June 1969), p 33. 
The first post audit should be conducted when it is determined that the project is completed and has had time to iron out operational difficulties. This should be held as close to the scheduled completion date as possible. Management will normally require a final audit after six months to a year of operation. Other than these, audits are usually scheduled only if the results of the first audits are unfavorable and corrective action is taken, or if performance is predicted to change substantially over time. As in selecting projects and audit factors, it is important that the first audit date be established at the time of the original proposal. 


\section{CHAPTER VII}

\section{RESPONSIBILITY FOR POST AUDIT}

Once the decision has been reached to begin auditing capital expenditures, most companies are faced with the fundamental problem of which department or group of departments within the firm is best equipped to conduct the post audit. "This decision may well be very important in the installation of a followup system."I

As evidenced in the literature, there is a significant danger in making this decision before gaining a thorough understanding of the kinds of measurements this type of audit must make to be fully productive. "The audit should be conducted by a person who is both familiar with the project evaluation process and the company's operations and objective in his approach." 2 "This type of audit (specifically $R$ \& $D$ projects) is not the usual accounting audit. The probing discussed here is beyond the scope of the accounting function." 3

1 Robert K. Jaedicke, Rate of Return Verification By Follow-up," NAA Bulletin, 41, No. 10 (June 1960), p. 63.

2 Patrick S. Kemp, "Post-Completion Audits of Capital Inves tment Projects," Management Accounting, 47, No. 12 (Aug. 1966), p. 54 .

3 Arthur J, Weinberger, "Post Audits and Qualitative Factors," Chemical Engineering, 17, No. 9 (April 1964), P. 165. 
Because of the variance between cash flows and traditional accounting data, it may be unwise to entrust the post audit to the accounting department. Nor should the post audit be carried out by the same group that proposed the projects being studied; they are likely to find that the projects were brilliantly conceived. Instead, it seems more appropriate to establish review teams made up of accountants, engineers, business economists, and some of the young executives who need an inftial exposure to the process of evaluating capital investments. 4

To establish the type of direction provided by the research literature, each author's position on assigning post audit responsibility is summarized below:

Survey Question: Who in the organization should have post audit responsibility?

Answers:

19 authors

8 authors

4 authors

1 author

3 authors

2 authors

6 authors

1 author
No direction given

Accounting department only

Accounting department working with other (operating) departments

The company's CPA firm

An internal, objective, and knowledgeable person

The project originator(s) (operating people)

A post audit team

An independent centralized group

4 Robert $W$. Johnson, Capital Budgeting (Belmont, California, Wadsworth Publishing (O., 1970), P. 15. 
Clearly, the literature does not provide a uniform solution to the problem. For better visability, the rationale used by authors choosing to elaborate on this subject can be separated into four distinct positions:

\section{Audit by Accounting}

The preparation of the savings reports should, in all cases, be the responsibility of the Cost Accounting Department. All departments should provide this department with the necessary data from which a cost savings report can be prepared. This is emphasized because departments other than cost accounting are not expected to know how to give proper effect to overhead or taxes. Trained cost accountants can tell when all factors in the problem have been properly reflected in the savings. 5

The controller's department actually performs about 95 per cent of the work required in the preparation of a post audit. We call on the other departments only when we have to and then try to take as little of their time as possible. 6

2. Audit by Project Originator

In all but a few of the 24 firms (surveyed), the data for the postaudit are gathered either by the originator (engineer, plant manager, or foreman) of the proposal, or, in the case of major proposals, by the staff of the screening body. This arrangement is logical because these people are directly concerned with the project and have been familiar with it since its inception. Where the results of the postaudit study are, however, used directly or indirectly to measure the ability of the originators of capital-expenditure proposals, dependence on these same personnel for the material with which to make the measurement would tend to invalidate

5

Winfield I. MaNeill, Effective Cost Control Systems (Englewood Cliffs, N. J., Prentice Hall, Inc, 1965), P. 174.

6 Robert E. Caughron, "How We Follow Up Capital Expenditures," NAA Bulletin, 46, No. 7 (April 1965), p. 47. 
the study. The executives of the firms who indicated that the originators in any way supply data for the post audit of their project were asked to describe how this tendency to color data, if it exists, is overcome. In eight firms, the appropriate members of the controller's staff spot-check the accuracy of the actual operating data provided by the originator who is performing the auditing function. In five firms, no action is taken to insure veracity of postaudit data supplied by originators. The executives of these firms unanimously agreed that they had no problem with a tendency to color data.?

If the audit is used to evaluate the analyst, someone other than the analyst should probably do (or at least review carefully) the work. On the other hand, the analyst may be the person closest to the project and he may be able to do an effective follow-up report with the least cost and effort.

3. Audit by Accounting and Operating Personnel

Audit responsibility is often placed with the corporate headquarters finance and accounting staff. Since financial personnel are sometimes unable to assess technical aspects, (some) companies assign audit responsibilities to finance and engineering. 9

Many firms do not depend upon proposal originators to supply postaudit data on completed projects. Instead, the postaudit is performed either by designated members of the controller's staff or members of the screening body. Actual operating data are obtained with the help of operating personnel who may or may not be the originators of the proposal. This manner of obtaining postaudit information definitely assures more accurate data. The individual firm must achieve a balance between having postaudit conducted by originators at a small

7 Donald F. Istvan, Capital Expenditure Decisions (Indiana University Business Report No. 33, 1961), Pp. 41-42.

8

Jaedicke, 요. cit., p. 63.

9 Wendell M. Childs, "Management of Capital Expenditures," Management Accounting, 5i, No. 7 (Jan. 1970), p. 40 . 
coat in man-hours (due to their familiarity with the project) but with a possibility of coloration, and having "independent" postaudits conducted by screening specialists or controller's personnel at a greater cost in man-hours and dollars.10

Where responsibility for post-audits rests at headquarters, it is usually the controller's function. The internal auditing, central accounting, or the budget departments usually do the actual work. Internal auditing is the unit most frequently assigned to this task.

The principal reason for the assignment of postaudit responsibility to financial and accounting personnel is that the implications of cost-saving or profit-motivated capital projects are primarily financial, and the results are often linked to or reflected in changes in operating budgets.

One reported drawback in having financial and accounting personnel conduct postaudits is that they are usually unable to assess the technical aspects of the projects they audit, and must therefore rely on the work of the engineers and technicians who were responsible for or associated with the original proposals. Several firms attempt to overcome this by assigning joint responsibility for posfaudits to central staff accounting and engineering. If

The preparation of performance reports usually is the joint responsibility of originating officials and -ither the accounting department or some other financial organization established for the specific purpose of capital expenditure review and analysis. Ocasionally, reviews are conducted by internal audit staffs.12

Practice is not highly variable on this point because the work is done by accountants in the majority of cases. However, there are questions as to which persons in the accounting organization

10 Istran, op. cit., p. 42.

11 N. E. Pflomm, Managing Capital Expenditures (The National Conference Board Business Policy Study No. 107, 1963), PP. 82-83.

12 John B. Matthews, "How To Administer Capital Spending," Harvard Business Review, 37, No. 2 (Mar/Apr. 1959), p. 96. 
should do the work and whether accountants are fully qualified to do the job. The "qualification" of accounting and financial analysts to do post audit work usually hinges on the following points:

1. Certain phases of project analysis are engineering oriented. Projects often include such factors as technical methods, machine speeds, materials usage, and apace utilization. Engineering and production specialists are usually better equipped to handle these matters than accountants and their work will be needed both in project estimating and in post audit. In many companies this problem is resolved by having the accountant or financial analyst obtain the relevant data from the engineers.

2. Production and engineering personnel will frequently resist the efforts of accountants to obtain the data needed for post audit. If this becomes a serious problem it may be helped by placing the management responsibility for post audit upon the managers to whom the technical people report. In very difficult situations it may be necessary to assign the full analysis task to the technical people themselves, even though this may involve sacrificing the benefits of uniform and rigorous financial analysis. 13

\section{Audit by Team}

Where administratively practical the post mortem should be performed by, or reviewed by, a team of experts independent of those from whom the project originated. This team should always contain one or two senior members of the capital budgeting department, but in the interest of the department's reputation for impartiality, $\frac{i t}{4}$ should never consist exclusively of such members. 14

The problem of trying to decide who should perform the audit is avoided to a large extent by dividing the responsibilities among those best qualified to perform portions of it. Some argue, for example, that the

\section{National Association of Accountants, Financial}

Analysis to Guide Capital Expenditure Decisions, Research Report No. $43(1967), \mathrm{P}^{2} 8 \%$

14 A. J. Merritt and Allen Sykes, The Finance and Analysis of Capital Projects (New York, John Wiley and Sons, Inc.. 1963), p. 389. 
Internal auditor should perform it because of his independent position. others argue for the originator of the proposal because of his familiarity with the variables he considered. Still others argue for the operating people because of their familiarity with the direct problems of implementing the investment. Teams made up of all three have been suggested to gain all of these benefits. The idea of splitting up the audit into its components and then reassembling it, is close to the team idea but has the added benefit that the team members do not have to coordinate their activities so closely with one another or even agree with one another. 15

An alternative approach is that of using postaudit team made up of both the people involved in the justification study and one or more "outsiders" from, say, the corporate controller's staff. Such a group would have a high degree of familiarity with the project to be audited, and--at the same time-an element of objectivity could be maintained.16

For uniformity, efficiency, and independent review, a centralized group, as designated by management, may prescribe procedures and audit the performance of the followup activity independently. The computations and explanations of variances should be performed by those having the necessary technical background within the respective operating department. An exception would be a project involving several departments, in which case a designated centralized group, technically qualified, should be assigned the followup duty. The technically skilled group in the operating departments should have at its disposal the necessary data from the accounting-information system

close liaison and cooperation would be required.17

Since much of the rationale for each of these positions seems logical, the practitioner is left with little in the way of proven direction. The decision therefore will be

15 Wandell J. McCorvey, "Auditing the Capital Budgeting Decision," Cost and Management, 43, No. 4 (May/June 1969), p. 33.

16 David V. Heebink, "Post Completion Audits of Capital Investment Decisions," California Management Review, 6, No. 3 (Spring 1964), pp. 49-50.

17 Milton F. Usry, Capital Expenditure Planning and Control (Austin, University of Texas, 1966), $\mathrm{p} \cdot 11$. 
fudgmental and in all probability strongly influenced by the organization and personalities within his business unit. At least one conclusion can be drawn however. To be meaningful, the audits must be conducted by knowledgeable individuals, technically familiar with the project and with cost accounting and audit procedures, but with heavy emphasis on objectivity. This criteria tends to preclude the original project estimator and/or project coordinator from having the sole responsibility for the audit and makes it equally difficult for the accountant. The best approach would seem to be that overall responsibility for post audit be assigned to the company controller and that actual work on the audit be conducted by a team of accounting and technical personnel. Company or division management would be required to determine individuals most qualified and appropriate for specific post audit assignments. Project engineers, accounting personnel, manufacturing and plant engineers and production supervisors could be drawn upon to support this task. The completed post audit report would normally be submitted for review by such persons as the plant manager, general manager, controller, manufacturing manager and others directly concened with the performance of present and future capital investments. Copies of each completed post audit report would be forwarded to the corporate controller and to the corporate auditor's department. 
CHAPTER VIII

\section{PREREQUISITE ACTIONS}

Thus far, this survey has reviewed the basic elements of post audit and the problems associated with each, as recognized in the literature. In most areas it is apparent that a certain amount of preplanning would do much to alleviate these problems and to facilitate the audit process. "Advance planning for post audit work is necessary if it is to be carried out on an efficient and meaningful basis." 1

It seems appropriate, therefore, to look to the literature for guidance on the "planning" requirements of a post audit program. To establish the type of direction provided by the research literature, each author's position on advance planning for post audits is summarized below: Survey Question: What prerequisite actions are required at the time the original proposal is submitted, to ensure effective post audits?

\section{Answer: ${ }^{2}$}

31 authors No direction given

4 authors "Plan" for the post audit

1 National Association of Accountants, Financial Analysis To Guide Capital Expenditure Decisions, Research Report No. 43 (1967), P. 89.

2 The total number of responses does not agree with the number of writers surveyed (44) since several offer more than one recomnendation. 
7 authors

6 authors

3 authors

1 author
Document what was originally expected of a project and the basis (including assumptions) for such expectations. Plan for data collection

Establish date of the audit Identify projects to be audited

The results of the survey are somewhat disappointing in that so few authors choose to address the planning aspect. Some of those that do however, tend to be quite emphatic in their remarks though general in direction.

The importance of the preplanning function and of delineating in detail the various facets which when completely assembled make up the finished economic document which is the support of the proposed capital expenditure cannot be over-emphasized. If the principal object of the post audit function is to determine the errors in judgment made when preparing the original justification, then the justification data must be prepared in such a manner that actual experience can be compared with it. ${ }^{3}$

Management can probably better forecast and control startup date with techniques now available, if its importance is realized, because the factors for startup are decided and controlled by management. If these are all meticulously established and quantified, the schedule can be accurately timetabled and followed. 4

The value of preplanning is apparently more meaningful

to those having actual experience at performing post audits.

3 Robert E. Caughron, "How We Follow Up Capital Expenditures," NAA Bulletin, Vol 46, No. 7 (April 1965), pp. 49-50.

4

Ross Henderson, "Improving the Performance of Capital Project Planning," Cost and Management, 45, No. 5 (Sept/Oct. 1971), p. 41. 
This point (advance planning) was emphasized several times in this research by those who are directly responsible for the conduct and review of post completion audit studies. Advance planning, in this instance, refers to establishing the original project justification in terms which can be identified and measured in the audit stage. Company experience shows that this "before and after" comparability can be achieved if the basic quantities and dollar measurements are clearly stated in the project analysis. It is also desirable to anticipate the type and form of actual data which will be readily available from future reports. 5

In the future it will be necessary for us to pay more attention to the study and development of projects prior to the writing of a recommendation for an appropriation. Such a program, as well as more scientific and formalized method of evaluating the results of our expenditures, is being worked on and in progress.6

Other authors mention specific areas of concern for which preplanning at the time of original proposal or approval is essential:

1. Identification of projects to be post audited

This element is of concern because of the obscure way It is handled by the literature. All but one of the authors recognizing the need for preplanning audits, fail to specify the need to identify which projects will be audited, except by implication. Yet most writers acknowledge the impracticality of auditing all capital projects and go on to point out that existing recordkeeping systems usually must be modified or supplemented before they will support a postaudit program.

\section{5}

National Association of Accountants, Financial Analysis to Guide Capital Expenditure Decisions, Research Report No. 43 (1967), PP. 89=90.

6 Robert W. Griffin, "How We Follow Up on the Capital Expenditures We Have Made," NAA Bulletin, 39, No. 3 (Nov. 1957), P. 66 . 
2. Documentation of original justification data

In this area the problem is summarized best by Killough:

Unfortunately, because of laxities in planning requirements, a major task in many post audits is to at tempt to determine what was originally expected of a project and the basis for such expectations.7

Supporting this point, at least three authors offer

both recognition and clear direction regarding the importance of proper (initial) documentation.

The essence of any good system of control is adequate prior documentation. Fundamentally, business measurement deals with establishing a plan or course of action, and then controlling by isolating and analyzing deviations from the plan. Obviously, if the prior documentation is inaccurate and incomplete, the ability to control is seriously limited.

In the case of capital expenditure programmes, adequate prior documentation is needed for two important reasons: (1) to provide the data required by the approving authority to make the investment decision, and (2) to document the plan for business measurement purposes.

From a control viewpoint, an important step in assessing the quality of the business planning is to clearly identify the assumptions that have been made with respect to significant environments ahead.

Documents in an appropriations request are used to provide a basis for post appraisal to determine if the $e$ timated benefits were achieved or nof, and the reasons for differences should they occur.?

The justification data which were used for budget purposes will be the basis of this (post audit) work. Considerable amplification and refinement will be

7

Larry N. Killough, "Planning and Control For Capital Facility Decisions," Budgeting, 15, No. 5 (Mar/Apr 1968), p 14.

8 W. R. C. Blundell, "Control of Capital Expenditures," Canadian Chartered Accountants, 92, No. I (Jan 1968), P. 36.

9 C. E. Edge, "Capital Budgeting: Principles and Profections," Financial Executive, 33, No. 9 (Spring 1965), p. 47. 
needed to produce a record which will bear critical analysis, which will be filed as the expressed judgment of the project's sponsors, and which will be checked against performange at intervals during the project's operating life. 10

3. Cost planning and data collection

In Chapter $V$ it was clearly established that traditional accounting recordkeeping systems are inadequate to support the data requirements of post audit. The preplanning of data collection to overcome this problem, receives only minor attention in the literature:

It is obvious that the requirements for grouping costs for property-record purposes are not the same as the requirements for grouping costs for project control. In fact if the property-record philosophy of cost records is maintained throughout project performance, it can result in an overwhelming task of recording and reporting, with consequent damage to cost control and to project performance. To avoid this, cost codes used during project execution should be tailored specifically for efficiency of project performance. At the conclusion of the project, the project-coded costs are translated into appropriate property records by having a cost engineer familiar with the project allocate portions of the installation cost accounts to the individual pieces of equipment. This can be done more realistically than by attempting to record the costs precisely as they occur.11

Regardless of whether a project is large enough to have its own permanent accounts, the postaudit can be executed more efficiently if it is planned for at the time of the fustification study. When this is done, the data in the study can be presented in such a way that it is more readily audited, and preliminary plans for the audit can be developed. In this connection, it should be noted that justification studies often disregard quantitites which are not affected by the decision in question; in

10 Horace G. Hill Jr., "Capital Expenditure Management," Jounnal of Business, 28 , No. 4 (Oct. 1955), p. 288.

11 John W. Hackney, Control and Management of Capital Projects (New York, John Wiley and Sons, Inc., 1965), p. 247. 
other words, comparative figures are used. Accounting data, on the other hand, are not usually generated in a manner that facilitates such comparisons. As a result, some ingenuity may be called for in making data-gathering plans for a postaudit. 12

In discussing the accounting system as an obstacle to post-completion audits, McCorvey suggests that the problem can be overcome by:

(1) modifying the present accounting system to collect costs on a project basis or (2) install a parallel system to collect the needed data. These methods imply that the needed modifications should be planned at the time the project is approved.13

4. Establish audit timing

In evaluating the literature's position on audit timing (Chapter VI), one important conclusion related to a failure to recognize the absolute necessity for establishing the date of initial audit during the investment approval stage. The research found that this point is almost entirely overlooked in the literature except for the following statements:

The post-completion audit should be planned at the time the investment is approved 80 that all necessary data that are not in the original accounts might be collected and the timing of the audit decided upon. 14 The audit date is established at the time the proposal is submitted for management approval. 15

Binzel is much more specific:

In the initial phases of my company's postinstallation appraisal program, the need for better documentation of the original estimates and data

12

David V. Heebink, "Post Completion Audits of Capital Investment Decisions," California Management Review, 6 , No. 3 (Spring 1964), pp. 51-52.

13 wandell J. MeCorvey, "Auditing the Capital Budgeting System," Cost and Management, 43, No. 4 (May/June 1969), P 31. 14 Ibid., P. 33

15 Keith J. Bowman, "We Follow Up Capital Expenditures," NAA Bulletin, 39, No. 7 (Mar 1958), p. 92. 
accumulation procedures for projects scheduled for appraisal became evident. This pointed up a strong incentive to identify projects scheduled for postinstallation appraisal at the time of initial approval. Sach a procedure permits arrangements to be made to accumulate revenues, costs and expenses, etc., in sufficient detail in the actual accounts so that they later can be identified and reconciled with the project estimates.

In order to perform a meaningful post-installation appraisal, and as support for the appraisal report, the following pre-investment information, to the extent applicable to a given project, is required:

1) The original economic evaluation and justification for the project.

2) The economic evaluations prepared for the various alternate cases that were considered but rejected.

3) The major assumptions and premises on which the economic (and intangilbe) justification was based.

4) All other supporting background material fhat was considered in the original project evaluation. If

There is little question as to the value of post audit proplanning. In a practical sense, it is highly unlikely that a post audit could be performed effectively without preplanning. The danger is that this is such a simple conclusion that it is perhaps too obvious, and may well be overlooked in the initial stages of a new post audit program. Unfortunately, the preponderance of literature on post audit does not communicate the importance of this to the practitioner, who in all probability will have to make the discovery through experience.

16 Philipp W. Binzel, "Economic Justification for Capital Expenditures, The Internal Auditor, (Spring 1965), P. 47 . 
If the planning function is performed as thoroughly as it should be, then the post audit function becomes relatively simple. Relatively simple because the knowledge to perform a good post audit was gained in the preplanning stage. When performing the post audit, follow the trail blazed during the planning function.

17 Caughron, Op. cit., p. 52. 


\section{CHAPTER IX}

\section{SUMMARY OF FINDINGS}

The objective of this paper was to ascertain the validity of the charge that present-day literature on the subject of capital budgeting fails to adequately address the post audit phase of capital expenditure prograns. Specifically, the study was intended to provide an objective comparison and analysis of present-day writings on post auditing in an attempt to answer the following questions:

1. Does general agreement exist among writers on what constitutes the basic elements of post auditing?

2. Within each of these basic elements, has the literature established a generally accepted set of operating principles to guide the practitioner?

3. In general, has the literature to date, individually or collectively, presented an approach to post auditing which is sufficiently structured to enable the practitioner to develop an effective post auditing program and to proceed with implementation?

Research material was gathered from library and bibliographical references with the intent of including most of the articles currently available on post audit. From this 
research, forty-four articles were found to contain sufficient material to be included in the survey.

The survey itself was structured around seven basic elements of post auditing which were selected after a thorough search of the literature revealed them to be the only items of substantial interest to the authors involved. It is the position of this paper that these elements are basic and fundamental to an effective post audit program.

The survey findings provide an answer to the first question by a simple tabulation of the number of writers which recognized and discussed each of the elements surveyed.

\begin{tabular}{lcccc}
\hline & \multicolumn{2}{c}{$\begin{array}{c}\text { DISCUSSED BY } \\
\text { THE WRITER }\end{array}$} & $\begin{array}{c}\text { NOT DISCUSSED } \\
\text { BY THE WRITER }\end{array}$ \\
\cline { 2 - 5 } & $\begin{array}{c}\text { NUMBER } \\
\text { OF AUTHORS }\end{array}$ & $\begin{array}{c}\text { ARTICLES } \\
\text { SURVEYED OF }\end{array}$ & $\begin{array}{c}\text { NUMBER } \\
\text { AUTHORS SURVEYED }\end{array}$ \\
\hline $\begin{array}{l}\text { Purpose } \\
\text { Importance }\end{array}$ & 40 & 918 & 4 & 98 \\
Project Selection & 19 & 438 & 25 & 578 \\
Audit Factors & 28 & 648 & 16 & 368 \\
Data Sources & 14 & 328 & 30 & 688 \\
Audit Timing & 26 & 598 & 18 & 418 \\
Audit Responsibility & 25 & 578 & 19 & 438 \\
Prerequisite Actions & 13 & $\underline{308}$ & $\underline{31}$ & 708 \\
\cline { 2 - 4 } Totals & 165 & 548 & 143 & 468 \\
\hline
\end{tabular}


A possible fallacy with this approach is the assumption that there is a correlation between the mention of an element of post auditing by an author, and the importance he attaches to it. However, since the purpose here is to evaluate the written material available to the practitioner and not the unpublished views of the author, the correlation would seem valid.

Conclusion

Although the study shows a considerable variation in the number of authors addressing each of the elements surveyed, it can reasonably be concluded that, with the exception of audit purpose, general agreement does not exist among writers on what constitutes the basic elements of post auditing.

The second question is more complex. To determine whether the literature has established a generally accepted set of operating principles, it is necessary to analyze the treatment of each element individually.

a) Purpose and Importance: The survey leaves little doubt that the literature has established a generally accepted principle regarding the primary purpose of post audit. Virtually all responses center around the evaluation of project performance as the initial procedure. Somewhat less agreement exists regarding the specific objectives of post audit, (i.e., the ultimate use of the knowledge 
gained through the evaluation). Several authors exploit the full potential of this information by suggesting a number of productive management uses. In total, however, the literature seems to underutilize this potential and could have been more helpful to the practitioner by addressing the full range of applications available.

b) Project Selection: Fifty-seven percent (578) of the literature (25 authors) did not believe this element to be of sufficient importance to warrent comment or left the implication that all of a firm's capital projects hould be audited. Only six authors (148) recognized that to satisfy most of the potential benefits of post audit, all large projects, and a sampling of small projects, should be selected for auditing. Several authors believe that all "large" projects be audited but suggest differing criteria for identifying these projects such as project significance, degree of uncertainty, or apecified dollar value threshold.

Based on the lack of direction found in the survey, it is reasonable to say that the literature has not provided a generally accepted set of principles for the selection of projects to be post audited. 
c) Audit Factors: The survey produced a total of 55 separate audit factors from the 28 articles offering specific direction. These factors were found 227 times in the literature, for an average of eight factors per author. Surprisingly, no single factor was mentioned more than sixteen times and only five factors were discussed by ten or more authors. The five, labor usage, equipment performance, capital investment, project profit and 1088, and cost savings, are all very important, but do not begin to describe the field of investigation required by a comprehensive post adit.

Considering the range of factors available, and the importance of each in helping to define the scope and basis of evaluation of the post audit, it is evident that the literature has not yet established a generally accepted position on the selection of audit factors.

d) Data Sources: Most authors writing on post audit make no mention of the problems associated with the sources of audit data. Thirty of the forty-four articles surveyed (688) fail to acknowledge the sourcing problem and in so doing, imply that existing accounting records are adequate in furnishing the required data. 
There is a very strong minority opinion, however, which refutes this claim and contends that the needs of audit information 80 far beyond that which is provided by traditional accounting systems.

Since the literature is polarized at opposite ends of an issue as important as this, it is obvious that there is no generally accepted position on the proper sources of audit information.

e) Audit Timing: On the question of post audit timing, the survey was divided into three parts: the initial audit, the second audit, and any subsequent audits. The last two parts were further refined to establish the conditions under which each of these audits should be conducted.

Responses to timing the initial audit range from the beginning of project operation to several years after this date, with eighteen authors ignoring the subject entirely.

Even fewer authors (15) sought to give guidance on the timing of a second audit with suggestions as diverse as "one year after start-up" and "continually." of these fifteen, only eight chose to specify the conditions which warrent a second post audit, and here there is a consensus that it should be conducted only where "necessary because the project did not meet expectations." 
Responding on the timing for audits subsequent to the first two, fourteen authors ( 328 ) suggested a total of thirteen somewhat different views on the appropriate time period. Regarding the conditions which justify these audits, seven authors are almost evenly divided between "large or long life projects," and "failure to meet expectations."

Repeating from Chapter VI, a major cause for the widely divergent guidance offered by the literature is the fact that the nature of the project itself determines to a large degree the most appropriate timing. Unfortunately, this is of little help to the practitioner, and it mast be concluded that the literature has been unsuccessful in establishing any generally accepted guidelines.

f) Audit Responsibility: It is generally agreed that assignment of audit responsibility to the proper individual(s) is an important step in the post audit process. The literature, however, does not provide a uniform recommendation on this assignment. In the survey, twenty-five authors responded to the question and are evenly divided on who should be given the primary responsibility; half favoring the accounting area, the other half suggesting other functional areas or the team approach, and one preferring to use the company's CPA firm. 
It could be said that the literature has established a generally accepted principle by recognizing the accountant's role as at least a participant in the post audit process, but past this point, a uniform direction has not been provided.

g) Prereguisite Action: Perhaps the most surprising result of the survey was the very limited response to the question of post audit pre-planning requirements. In light of the number of other significant problems discussed in the literature, it would be normal to anticipate a heavy emphasis in the planning area. To the contrary, only thirteen authors ( 308$)$ made specific mention of the importance of post audit planning. Reasons for pre-planning include: general principles, proper documentation, data collection, timing, and project identification. Direction in each of these areas is at best general in nature.

The literature obviously has not established general acceptance of any guiding principle for post audit planning.

Conclusion

Seven basic elements of post audit were surveyed in this study. As a reminder, these elements were chosen after a thorough search of the literature revealed them to be the 
only items of iubstantial interest to the authors involved. Although it was concluded, earlier in this summary, that general agreement does not exist among writers on the basic elements of post auditing, it is important to understand that these elements constitute almost all of the literary discussion surveyed, and, therefore must be used in any evaluation of the cohesiveness of that literature.

Summarizing the findings for each element, it is evident that the literature has not established a generally accepted set of operating principles to guide the practitioner in the practice of post audit.

The third question is partially answered by the previous two conclusions but is subject to the following important qualifications:

1. Since this survey established that a wide variation exists between the views of the authors surveyed on a number of key areas, and further, that in most areas studied, no consensus of opinion stood forth as the dominate position, no attempt was made to analyze individual articles to determine the percentage of time the authors' views corresponded to the majority position.

2. While it is not the purpose of this paper to provide evaluations of individual articles, it can be said from general observation that some of the references surveyed were far more comprehensive than 
the majority of those appearing in the literature. Reference to these particular articles would admittedly provide more direction than would the literature at random. On the other hand, no individual article reviewed in this survey was thought to contain sufficient detail and direction to provide an adequate basis for establishing an effective audit program.

3. If the practitioner has the time and the inclination to conduct research on the level of this paper, he would most certainly be better prepared to organize and implement a post audit program than if he were to rely on one or two references or on a cursory review of several articles.

\section{Conclusion}

To answer the third question, if a general agreement on the basic elements of post auditing has not been reached by the literature and the writers have not yet established a generally accepted set of operating principles, it follows that the literature surveyed, individually or collectively, has not presented an approach to post auditing which is sufficiently structured to enable the practitioner to develop an effective post auditing procedure and to proceed with implementation. 
In the introductory chapter, a number of charges relating to the inadequacy of present-day literary treatment of post auditing capital expenditures, were quoted from some of the authors making up that body of literature. At the conclusion of this research, I have little doubt as to the validity of these charges.

Further Observations

Throughout this paper, the evaluation has necessitated occasional reference to additional factors and direction which I believe would be of benefit to the practitioner. In order to make a meaningful contribution to this body of knowledge, the following thoughts are offered for the reader's consideration:

1. The fundamental elements of any post audit program as outlined in this paper are:

A. Purpose and importance

B. Project selection

c. Audit factors

D. Sources of information

E. Audit timing

F. Audit responsibility

G. Prerequisite actions

2. The initial step in the implementation of an effective post audit program is to gain a basic understanding of these elements and to establish specific policies and action plans regarding each of them. 
3. Within each element, certain basic considerations should be regarded as fundamental:

A. Purpose and importance: Post audit programs offer a multitude of worthwhile benefits and should not be restricted to a narrow statement of purpose if they are to be fully utilized and cost effective. The statement of purpose should describe the program in terms of specific objectives (i.e. use of the information developed by the audit) but should not attempt to elaborate on the mechenics of producing that information. This type of detail, though important, is best left to the areas of project and factor selection, information sourcing, audit timing, and preplanning.

The statement of purpose should also recognize a clear distinction between routine post audits for general business reasons, and special purpose audits conducted to achieve specific management objectives. Requirements for each of these can be quite different and must be thoroughly understood before proceding with the program.

Finally, in preparing the statement of purpose, particular attention should be paid to the importance of defining as precisely as possible 
the minimum amount of information needed to accomplish the objectives. For example, even though most capital investment programs are proposed and approved on the basis of return on investment or some similar calculation, it is rarely necessary to carry out a post audit study to that degree to achieve maximum benefit from the audit. In most cases, the principal value of post audit is derived from measuring the basic (underlying) factors of investment performance such as implementation cost and timing, operational rates, production costs, physical performance to original plan, physical problems encountered, and corrective action applied or recommended. These kinds of factors determine to a large extent the success or failure of a project leaving little to be gained by requiring the laborious recalculation of return on investment, until satisfactory project performance is achieved at the working level.

B. Project Selection: It is generally considered both impractical and unnecessary to audit all of the capital investment projects within a firm, regardless of company size. In the case of general purpose audits, perhaps the best approach is to audit all very large projects cover a 
selected dollar investment) and a sampling of smaller ones.

Special purpose audits must obviously concentrate on the investments in a given area and can be performed on the same basis as above or may encompass all of the projects in that area depending upon the number of investments involved.

of critical importance, is the identification of projects for audit at the time of original justification and approval. This is an essential step in post auditing since it is only at this time in the capital expenditure program that the original factors and assumptions, which will be later audited, can properly be identified and documented.

c. Audit Factors: The selection of factors to be audited defines the scope of the audit, and, to a large extent, the degree to which meaningful results will be produced. In effect, the factors selected, form the basis of the evaluation and determine, in advance, the potential value or lack of value of the audit, to company management.

These factors, in turn, identify the various functional areas from which audit information must be obtained. This is important in 
establishing the sources of audit information as well as the types of information required, particularly where data is to be expressed in other than dollar terms, or on a basis different than traditional accounting periods.

The research exposed several other important considerations to the selection of audit factors;

1. An essential part of effective post auditing is the advance selection of audit factors.

2. A post audit should concentrate on significant and basic factors which are "key" to the success or failure of a project.

3. To be meaningful, post audits must evaluate project characteristics using a basis compatible with that used to prepare the original justification.

4. The use of judgmental as well as quantifiable data is both appropriate and essential in communicating post audit results to management.

5. In order to properly measure those characteristics which are unique to individual investment projects, the audit should be tailored to the specific project and management purpose.

A large range of investment factors are available to, and frequently used by, the project estimator. The post auditor must review the factors used in the justification, and determine which will be measured by the audit. 
The success or fallure (or some degree in between) of each individual project is directly dependent upon achievement of performance estimates for certain "key" factors. The auditor will want to identify any external factors which did not materialize as forecasted, but should give primary attention to the "key" controllable factors which are not performing to expectations. These (internal) factors are often subject to corrective actions which can be applied to improve overall project performance.

D. Sources of information: The difficulty of obtaining useful audit information from existing record keeping systems should be recognized as one of the most formidable barriers to the post audit program. A first step toward solving this problem is the realization that much of the information required by post audit is non-financial in nature.

In practice the information needed varies with the type of project involved, the factors to be measured, and with the objectives of that project. In most cases, performance must be measured by a combination of financial and operational data too extensive and diverse for collection by any single system. Parallel or separate systems are similarly limited and much too costly to support a post audit system. 
The fundamental requirement for obtaining adequate audit informational sources is the study and preplanning for that information, before the project begins. Much of this information can only be obtained by the organization of special reporting and data collection systems specifically designed to support the audit. In my view, this fact is one of the chief reasons for the very limited acceptance industry has given the post audit technique. It is painful for management to admit that existing data systems, with all of their sophistication, generally fail to produce meaningful post audit information.

E. Audit Timing: Establishing the appropriate time to audit a project is as important as the decision on what factors are to be audited. Proper audit timing is normally determined by the nature and purpose of the project, the expectations established in the original justification, and to some extent, by the purpose of the audit itself.

The timing of the audit is a critical part of its effectiveness. It is the point at which we measure actual results and compare them with expectations (not the least of which was the calendar time the project was projected to be fully operational) to determine project performance. 
As a practical matter, few if any newly acquired assets are able to perform to optimum levels immediately after being placed in service. Therefore premature audits will be misleading and wasteful. On the other hand, the cost of being late with satisfactory project performance can be a serious consideration where loss of market position, revenues, or time penalties are involved.

The initial post audit timing must be established during project justification or approval, and is virtually dependent upon the implementation schedule used in that justification. The actual audit should be conducted on the date the project is scheduled to be operational (i.e. when the project is completed and has had time to iron out operational difficulties). Management should require a final audit after six months to a year of operation to verify operating results. Subsequent audits are usually justified only if the results of the first audits are unfavorable and corrective action is taken, or if performance is predicted to change substantially over time.

F. Audit Responsibility: The proper assignment of post audit responsibility is also important to the program. To be meaningful, the audits must be conducted by knowledgeable individuals, technically 
familiar with the project and with cost accounting and audit procedures, but with heavy emphasis on objectivity. This criteria tends to preclude the original project estimator and/or project coordinator from having sole responsibility for the audit and makes it equally difficult for the accountant. The best approach would seem to be that overall responsibility for post audit be assigned to the company controller and that actual work on the audit be conducted by a team of accounting and technical personnel.

Company or division management should determine individuals most qualified and appropriate for specific post audit assignments. Project engineers, accounting personnel, manufacturing and plant engineers and production supervisors could be drawn upon to support this task.

6. Prerequisite Actions: In a practical sense, it is highly unlikely that a post audit could be performed effectively without preplanning. Specifically, the following items must be accomplished well in advance of the actual audit:

1. Projects selected for post audit must be identified. 
2. The original justification must be thoroughly documented.

3. Cost and operational data definition and collection must be organized.

4. Initial audit timing must be established.

4. In the final analysis, the structure of an actual post audit program will be determined by each individual firm and the requirements of management. In the absence of any definitive work on the subject, those responsible for the program will have to organize on the basis of general literary guidelines, past knowledge, and experienced judgment. 


\section{BIBLIOGRAPHY}

American Institute of Certified Public Accountants.

"Analysis For Purchasing and Financing Productive Equipment." American Institute of Certified Public Accountants Technical Study No. 4 (1967).

Association of Consulting Management Engineers. "Capital Budgeting--How To Use It Constructively." Reprinted in Lemke, B. C. and J. D. Edwards. Administrative Control and Executive Action. Columbus, Ohio: Charles E. Merrill Books, Inc., 1961.

Baker, Kenneth A. "Management Reviews Capital Expenditures." Budgeting, 14 (Nov. 1965), pp. 14-19.

Binzel, Philipp W. "Economic Justification for Capital Expenditures." The Internal Auditor, Spring 1965.

Bishop, Bill J. "Effective Organization For Capital Expenditure Analysis." Management Services, 4, (July/Aug. 1967), Pp. 51-56.

Blundell, W. R. C. "Control of Capital Expenditures." Canadian Chartered Accountants, 92 (Jan. 1968), pp. 3538.

Bowman, Keith J. "We Follow Up On Our Capital Outlays." NAA Bulletin, 39 (Mar. 1958), pp. 91-92.

Caughron, Robert E. "How We Follow Up Capital Expenditures." NAA Bulletin, 46 (April 1965), PP. 47-52.

Childs, Wendell M. "Management of Capital Expenditures." Management Accounting, 51 (Jan. 1970), pp. 37-40.

Christy, George A. Capital Budgeting. Eugene, Oregon: Bureau of Business and Education, University of Oregon, 1966.

Dean, Joel. Capital Budgeting. New York: Columbia University Press, 1951.

Dean, Joel. "Measuring the Productivity of Capital." Harvard Business Review, 32 (Jan.-Feb. 1954), Pp. 120I30. 
Deekens, Arthur V. K. "Did We Realize On That Capital Outlay?" NAA Bulletin, 40 (May 1959), PP. 86-88.

Donis, Jack P. "Unresolved Problems in Capital Budgeting Application," Financial Executive, 35 (May 1967), PP. 73-79.

Edge, C. E. "Capital Budgeting: Principles and Projections." Financial Executive, 33 (Sept. 1965), Pp. 50-59.

Edwards, James Don. "Investment Decision Making In a Competitive Society." MSU Business Topics, 18 (Autumn 1970), pp. 53-60.

Fremgen, James M. "Capital Budgeting Process: A Survey." Management Accounting, 54 (May 1973), PP. 19-25.

Griffin, Robert w. "How We Follow Up on The Capital Expenditures We Have Made." NAA Bulletin, 39 (Nov. 1957), PP. 61-66.

Hackney, John W. Control and Management of Capital Projects. New York: John Wiley and Sons, Inc., Ig65.

Heebink, David V. "Post Completion Audits of Capital Investment Decisions," California Management Review, 6 (Spring 1964), pp. 47-52.

Heiser, Herman C. "Justifying Capital Expenditures--Before EAfter." NACA Bulletin, 38 (Sept. 1956), PP. 160-163.

Henderson, Ross. "Improving the Performance of Capital Project Planning." Cost and Management, 45 (Sept./0ct. 1971), PP. 33-41.

Hicks, Carl F. Jr, and L, Lee Schmidt Jr. "Post Auditing The Capital Investment Decision." Management Accounting, 53 (Aug. 1971), pp. 24-28, 32.

Hill, Horace G. Jr. "Capital Expenditure Management." Journal of Business, 28 (Oct. 1955), pp. 285-290.

Horngren, Cost Accounting, A Managerial Emphasis. Englewood ciiffs, N. J.: Prentice Hall Inc.: 1962.

Ireeson, W. G. and E L. Grant. Handbook of Industrial Engineering and Management. Englewood Ciffs, N. J: Prentice Hal I, Inc., 1955. 
Istvan, Donald F. Capital Expenditures Decision. Indiana University Business Report No. 33 (1961).

Jaedicke, Robert $K$. "Rate of Return Verification By Follow Up." NAA Bulletin, 41 (June 1960), pp. 59-64.

Johnson, Robert W. Capital Budgeting. Belmont California: Wadsworth Publishing Co., 1970.

Jones, Manley H. Executive Decision Making. Homewood, Illinois: Richard D. ITwin Inc., 1957.

Kemp, Patrick S. "Post-Completion Audits of Capital Inves tment Projects." Management Accounting, 47, (Aug. 1966), pp. 49-54.

Killough, Larry N. "Planning and Control For Capital Facility Decisions." Budgeting, 16 (Mar./Apr. 1968), pp. 9-15.

Killough, Larry N. "System Framework For Capital Expenditure Program Development." Management Accounting, 52, (Aug. 1966), Pp. 29-32.

McCorvey, Wandell J. "Auditing The Capital Budgeting Decision." Cost and Management, 43 (May/June 1969), PP. 30-32.

MaNeill, Winfield I. Effective Cost Control Systems. Englewood Cliffs, N. J.: Prentice Hall, Inc., 1965.

Matthews, John B. Jr. "How To Administer Capital Spending." Harvard Business Review, 37 (Mar./Apr. 1959), pp. 94-99.

Merritt, A. J. and Allen Sykes. The Finance and Analys is of Capital Projects. New York: John Wiley ह sons, Inc., 1963.

Montgomery, John L. "Appraising Capital Expenditures." Management Accounting, 47 (Sept. 1965), PP. 3-10.

Myers, Ronald E. "Performance Review of Capital Expenditures." Management Accounting, 48 (Dec. 1966), PP. 21-26.

National Association of Accountants. "The Capital Expenditure Control Program." NAA Bulletin, 40 (Mar. 1970), pp. 2429.

National Association of Accountants. "Financial Analysis To Guide Capital Expenditure Decisions." Research Report No. 43, 1967. 
Pflomm, N. E. "Managing Capital Expenditures," The Kational Conference Board Business Policy Study, No. 107, 1963.

Sollenberger, Harold $M$, and Alvin A. Arens. "Assessing Information Systems Projects," Management Accounting, 55 (Sept. 1973), pp. 37-42.

Solomon, Ezra. The Management of Corporate Capital. New York: Glencoe, 1959.

Terborgh, George. Business Investment Management. Washington D. C.: Machinery and Allied Products Institute, 1967.

Usry, Milton F. Capital Expenditure Planning and Control. Austin: The University of Texas, 1966.

Weinberger, Arthur J. "Post Audits and Qualitative Factors." Chemical Engineering, 17 (April 1964) pp. 165-168. 


\section{APPENDIX}

SELECTED EXCERPTS FROM THE LITERATURE ON THE PURPOSE AND IMPORTANCE OF POST AUDIT 
206

Wendell M. Childs, "Management of Capital Expenditures," Management Accounting, 51, No. 7 (Jan. 1970), P. 40.

A post-completion audit serves at least five major purposes:

1. Fosters a sense of responsibility in those who participate

2. Verifies savings or profits, or identifies ditferences

3. Reveals reasons for failures

4. Checks on soundness of managers' proposals and recommends any corrective action

5. Aids in assessing future expenditure proposals. 
Philipp W. Binzel, "Economic Justification for Capital Expenditures," The Internal Auditor, (Spring 1965), Pp. 4546 .

Basically, there are several reasons for postinstallation appraisals:

1) To provide management with information on how well new investments are panning out, i.e., to verify the resulting savings or profits.

2) To uncover areas where improvements can be made to individual projects or where remedial action can be taken to achieve planned objectives.

3) To disclose inadequacies in the form or content of appropriation requests.

4) To determine the soundness of original assumptions, policies and analyses--providing feedback for future decisions.

A sound post-installation appraisal program should be aimed at improving investment performance and presenting future error, rather than "pointing the finger" or the assignment of blame for past mistakes. Certainly, we do not want our managers to become overcautious and avoid proposing projects that are really needed rather than risk exposure to censure. However, when project sponsors know that the results will be checked, the quality of their capital expenditure proposals will have a tendency to improve. 
N. E. Pflomm, "Managing Capital Expenditures," The National Conference Board Business Policy Study No. 107 (1963), Pp. 80-81.

Post-completion audits, sometimes called makegood, or performance reports, serve four major purposes.

1. To verify the resulting savings or profit

2. To reveal reasons for project failure

3. To check on soundness of various managers' proposals

4. To aid in assessing future capital expenditure proposals.

The post-completion audit is usually the most reliable means of verifying the savings or added profit produced by a project. Some companies that do not make postaudits point out that such projects are closely tied in with unit operating budgets that will reflect the expected benefits. Others insist, however, that when results are not apparent, an audit is required to determine whether a project failed, or whether savings were realized as forecast but were offset by increased expenses elsewhere. Similarly, a post-audit is the only means of determining whether an improvement in operating results stems from the new capital project or from improved savings elsewhere.

A number of companies stress the value of the postcompletion audit in uncovering reasons for project failure. This aids management in taking corrective measures or, if there seems to be no means of making the project profitable, of abandoning it with minimal additional loss.

Post-audits also serve as a check on the soundness of capital expenditure proposals advanced by departmental or divisional managers. More importantly, according to a number of companies, managers who know that they will be held to account for the results of their proposals tend to make every effort to insure their reasonableness and accuracy. They also manage them carefully to avoid having to explain failures. However, most companies that stress this latter purpose also point out that 
managers should be informed that post-audits are made primarily to help them improve their abilities to manage capital investments. Otherwise, they may tend to become overcautious and to avoid proposing projects that are really needed rather than risk exposure to censure.

A few companies cite the value of post-completion audits in assessing future capital projects. According to these companies, it is often most helpful to refer to post-audits of past projects in estimating the chance of success of subsequent similar proposals. Also, post-audits indicate where changes in new project proposals will avoid past pitfalls. Finally, they reveal the tendency of various managers to be overly cautious or pessimistic in their estimates and thus permit adjustment to bring estimates for future projects closer into line with reality. 
Robert K. Jaedicke, "Rate of Return Verification by Follow-up," NAA Bulletin, 41, No. 10 (June 1960), pp. 60-6l.

It seems that there are at least three important advantages or objectives of follow-up reporting:

1. Provide information for decision-making.

2. Serve as a basis for corrective action.

3. Stimulate the realization of investment program goals.

If a reporting system does not accomplish at least one of these objectives, its value to a company is probably low. The three objectives are discussed below.

A system of follow-up reporting might provide information which can be used to make decisions or lay plans for a future period. Information on how recent projects have turned out may be a real aid in evaluating future projects. Companies may have repetitive investments. For example, the decisionmay arise every few years as to whether a fleet of automobiles should be purchased or leased, or a program of equipment replacement or modernization may have been undertaken over a long period of time. Certainly, it would help the management in the repeat decision to know how past similar projects have worked out. Furthermore, even if similar decisions are not made on a repetitive basis, follow-up information may be of value. It may be very important to calibrate the forecast against the results to see whether a particular analyst shows a predominant bias toward over or under-estimating. If this is the case, management may wish to make adjustments on future analyses even though the new projects are quite different from past projects.

A system of follow-up reporting may provide information which will help pinpoint a bad situation and serve as a basis for corrective action. If things are not working out as they were estimated, perhaps post-audit will show that additional "debugging" is necessary. It may be that 
a system of reporting and follow-up will be necessary to show when the review operations can be stopped on a certain project. If post-audit shows that some projects are not working out as expected and corrective action is impossible, this information might also be very valuable. It may be that certain investments have been put on the shelf because these "sour" projects were more favorable on a rate-of-return basis when the estimates were prepared. If follow-up shows big deviations from the estimates (even if corrective action is out of the question), it may be that the opportunity rate of return being used by the management is too high, that is, management may be keeping projects on the shelf which should be undertaken.

A third objective which may be served by a reporting system is to stimulate the personnel of the organization to keep their eyes on the goal and to progress toward this goal. The post-audit should serve to remind the production and research and development people that the analyses or estimates were not just a collection of useless facts or a guess at what will happen in the future. The post-audit should help make the estimate a program or a goal and challenge the personnel to realize this goal. 
Ronald E. Myers, "Performance Review of Capital Expenditures," Management Accounting, 48, No. 4 (Dec. 1966), pp. 21-22.

There are a number of advantages to incorporating such a review in the capital budgeting control system:

1. Management can profit in the future by avoiding mistakes of past investment decisions. Audits provide management with the hindsight of experience that can highlight areas where improved techniques of forecasting planning and budgeting can lead to better investment decisions.

2. Performance review assists in focusing attention on those responsible for the capital budgeting process. Individuals responsible for estimates and evaluations would tend to be more careful if they were assured that their projections would be compared closely with actual results.

3. Top management may want to filter out investment proposals with the personal bias of junior officers. Performance review provides a way of determining the extent to which a "bias corrector" may be applied to the projected return from a proposal.

4. A follow-up on performance can highlight existing deficiencies in investments so that corrective action may be implemented to bring the project up to performance expectations or, if necessary, to liquidate the project. Many times projects that fail to meet expectations are hampered by the omission of a vital component or variable. Timely knowledge of this fact can result in correction of the omission.

5. Performance review can be helpful in developing younger executives. 
National Association of Accountants, "Financial Analysis To Guide Capital Expenditure Decisions," Research Report No. 43,1967, P. 85 .

Two very constructive reasons for undertaking postcompletion audits are to gain knowledge which aids in present project analysis and to uncover further investment opportunities. Reasons such as these provide a positive basis for audit, as opposed to the post mortem atmosphere usually associated with after-thefact analysis. When project originators realize that the results of such studies can be used as a basis for new projects they are enthusiastic about getting the audits completed. Also, under such circumstances there is a greater incentive to conduct the planning and analyses for present proposals in a manner which will make the data susceptible to meaningful audit when the time comes. Some of the companies visited in this research have achieved this atmosphere of constructive feedback to some degree. In doing so they find that they are not beset with the resistance and inertia which so often surround project post audit programs.

From the detailed standpoint there are several purposes for post-completion audit procedures beyond the two broad purposes referred to above. These are:

1. To develop information about the pattern of error that is associated with different project originators or organizational units $(e . g$., divisions or departments) which submit investment proposals.

2. To learn lessons from project experience which can be used in increasing estimating proficiency and to improve estimating procedure.

3. To measure the ability of project engineers, planning analysts, or others who are directly concerned with project origination and evaluation.

4. To accumulate information and experience which can be used to develop or improve post auditing procedure. 
5. To determine whether corrective action is needed to bring a project up to its full potential and to provide information about what kind of action should accomplish the desired results.

6. To investigate implemented projects believed unprofitable and, based on analysis, to recommend abandonment. This purpose is similar to that of analyses of divestment opportunities.

7. To assign responsibility for mistakes and mismanagement in project implementation, either in installation or initial operation; or, to assign credit for good performance in these dreas.

8. To provide an over-all framework of control so that project origination, approval, and implementation will be a disciplined management process; and to advise both managers and specialists in advance that their project work will be subject to review.

Our research indicates that companies' procedures for post audit are heavily influenced by their managements' choice as to which purposes are dominant. 
John B. Matthews, "How To Administer Capital Spending," Harvard Business Review, 37, No. 2 (Mar/Apr 1959), p. 95.

There are number of advantages in making such a review a part of the administrative process:

(1) Management can profit in the future by avoiding a repetition of past mistakes. In more positive terms, experience can highlight areas in which better plans, policies, and forecasting techniques can improve capital expenditure activity.

(2) A follow-up or performance can spotlight existing weaknesses in order that current projects may be revised.

(3) Performance review can focus attention upon those individuals or organizations responsible for major or continuing errors. Of equal importance, it can reflect good performance and provide an incentive for better performance.

(4) If top managements are correct in believing that junior officials are too frequently overoptimistic in predictions for pet proposals, the knowledge that results are to be scrutinized can breed a healthy caution at the time of initial justification. (Admittedly, however, there is a fine line to be drawn here between overconservatism and discouragement of ideas.)

(5) Performance review can become a useful area for training younger executives whose span of knowledge and contacts top management wishes to broaden. Inquiry into reasons for project failure or success cannot be conducted on a rote basis, and the executive charged with responsibility for review necessarily finds himself involved in and developing skills in many areas, such as pricing, production, market analysis, and human relations. 
George Terborgh, Business Investment Management, (Washington, D. C.: Machinery and Allied Products Institute, 1967 P 252 .

There is first of all a check on personal bias. Some people are prone to overestimate the potential benefits of projects, others to underestimate them. The investment analyst cannot be expected to hit the bull's-eye in individual cases, of course--after all he is not clairvoyant--but he can be expected to average out over a large number of cases. If systematic post-audit shows off-center results in terms of averages, he should be moved to correct the bias, failing which the reviewing authorities should make allowance for it.

A second benefit from post-audit is the psychological stimulus to plant and process improvement. If the auditors can report to financial of $i$ cers and top management that prior investments have averaged up to predictions, it engenders confidence in new proposals. It is only natural for the "boss" to suspect that the analyst's estimates reflect excessive enthusiasm of the shop people for new acquisitions, and a record of successful estimation in the past is a valuable reassurance.

Thirdly, careful post-audit often results in increased productivity. The advantages listed on the project analysis sheet are not simply prophecies; they are in a sense a goal and a program. The audit reminds the production men that there was a program for the project, and challenges them to realize it. The resultant examination of failures and shortfalls can yield substantial benefits. 
Robert W. Johnson, Capital Budgeting (Belmont, California: Wadsworth Publishing (o, 1970), PP. 147-149.

IMPROVE FUTURE DECISIONS. The foremost objective of a post audit should be to improve future procedures and decisions concerning capital investments as well as their implementation. A feedback is necessary if we are going to learn from past mistakes and avoid them in the future. We are also aided in quantifying the degree of uncertainty that is actually experienced in making estimates and in identifying the type of estimate subject to the greatest degree of estimating error. This information enables us to institute programs to improve estimates in critical areas.

Since each proposal shows the name of the sponsor and the analyst, those individuals are likely to be more careful in making their estimates if they know they are subject to a post audit--just as we are more careful in making our tax returns with this knowledge at hand. This is not to say that post audit should be viewed as a punitive measure; this will only cause resistance. We wish to encourage honesty while not discouraging initiative. The post audit looks back, not to rake up old mistakes, but to avoid errors or biases in the future. The post audit procedures should make clear that, since the original project was based on probablistic estimates, we expect actual cash flows to vary from expected values. Our interest centers on estimators who are so consistently above or below actual outcomes that their errors of estimate cannot be viewed as random. Maybe we cannot get them to change their biases, but we can at least adjust their estimates at higher decision levels.

A post audit is particularly helpful in improving repetitive decisions in chain operations, such as banks, retail stores, and finance companies. A new machine, product, or service may be tried at one location. Then, on the basis of the post audit, its use may be expanded to all units, or to those where the post audit reveals it to be most profitable.

Post audits provide better future investment decisions directly, but they also prevent overall bad budgetry decisions. When capital investments are out of control, 
It becomes very difficult for senior management to know where to cut in order to live with available funds. Without information as to which divisions are over-optimistic or which are ineffective in implementing capital investments, the tendency is to cut budgets uniformly across the board. We have all seen cases where a political official tells all departments and divisions to cut their budgets or personnel by 10 percent. The social costs of such a cut are far from uniform, and it is a heavy added price to pay for past deficiencies in budgetary controls and audits.

REVIEW CONTINUING INVESTMENTS. For long-term investments it is inadvisable to wait until they have been terminated for a post audit. More will be said about this below. A post audit may reveal that there have been deficiencies in the implementation of an investment, so that prompt action may remedy the deficiency. A post audit may lead to a recommendation to terminate an investment. This is merely a negative capital investment, with the funds salvaged being offset by the cash flows sacrificed in later periods.

MANAGEMENT TRAINING. It used to be an adage of the small-loan business that you assigned a new employee first to the collection of past-due loans. That experience was calculated to teach him rather quickly the hazards of making bad loans. Somewhat the same reasoning suggests that young officers can learn a great deal from participating in post audits. Not only should it teach them sound economic analysis and expose them to many different departments in an organization, but it also shows them that capital investments are indeed based on probabilities and that the central-value estimate very seldom occurs in fact. As we shall see below, a post audit cannot be based solely upon accounting data in its usual form. Consequently, the young officer must learn to look behind the data and derive the figures necessary for making decisions--since by analyzing a past decision he is only reconstructing the data as if for a future decision. 
John L. Montgomery, "Appraising Capital Expenditures," Management Accounting, 47, No. 1 (Sept. 1965), p. 10.

Up to this point we have been concerned with details of how to follow-up on capital expenditures. The next question--why bother to audit capital expend1tures at all--can best be answered by the following comments :

1. The audit fosters a sense of responsibility in those who participate not only in the capital investment but in the planning of capital investment and in the use of capital later. If people understand that they are held accountable for the results and that the results will subsequently be audited, their care in exercising judgment is enhanced. Responsibility for planning and the planners of each phase can be pinpointed:

- Technical soundness of proposal.

--Financial appraisal of investment and control of expenditures.

--Achieving results committed by the investment. - Taking necessary corrective action.

2. The audit of a capital investment promotes control and corrective action. . in the one illustration - . the first-year results were below the efficiency called for by the overall project. We were therefore able to take corrective action and bring the results back into line.

3. The audit of capital investment is just good common sense--to know where you are, what your overall return on investment is and whether the investment in fact was worth the effort. You ought to know where you are in relationship to where you planned to be. 
Wandell J. McCorvey, "Auditing The Capital Budgeting Decision," Cost and Manasement, 43, No. 4 (May/June 1969), pp. 30-3i.

The post-completion audit has several benefits:

1. It helps ensure that estimates made by the people who prepare proposals will be more realistic because they will be checked.

2. It helps improve the future evaluations of capital expenditures.

3. It helps improve the performance of projects which have already been implemented but are not operating as planned.

4. It may point out projects which should be discontinued.

The mere fact that those who submit proposals know that their predictions will be reviewed should go a long way towards ensuring that they will be more careful and realistic in their estimates. There is a human relations problem here, though, in that managers may hesitate to submit any projects for approval and those which they do submit may be so conservative as to be useless. This problem will be discussed later. By reviewing past projects which have been reviewed and implemented, one can get an idea of what types of projects perform best, what kinds of forecasting methods are more accurate, and what kinds of ranking methods would give better results.

If an investment has been approved and an expenditure made, a subsequent review will of ten provide an convenient follow-up to make sure that the investment has been implemented in the way it was supposed to be implemented. For example, a machine intended to be used for one process may mistakenly be used for another process for which it is not ideally suited. This can be corrected and an unprofitable investment may be turned into a profitable one. In some cases, the audit may discover investments which simply did not work out and should be discontinued. 